A classificação e as regras de prevalência aqui propostas visam a oferecer uma estrutura racional para a argumentação jurídica que seja vinculada ao ordenamento jurídico, e com a qual possa ser diminuída a subjetividade na interpretação em favor de uma intersubjetividade cada vez maior. Um resíduo, maior ou menor, de subjetividade é inerente a qualquer interpretação. Quando se afirma que há uma parte objetiva e um resíduo de subjetividade na interpretação não se está pretendendo dizer que há fases que são somente objetivas e fases que são somente subjetivas. Não. Desde a mani pulação dos argumentos lingüísticos até o extremo da utilização de argumentos meramente práticos há uma insuplantável dialética entre objetividade $e$ subjetividade. $\mathrm{O}$ esforço do intérprete, e a função mesma da argumentação jurídica, é intersubjetivar o subjetivo. No final, restará um quê de subjetivo na argumentação. Mas um subjetivo que se pode ver. Na verdade, a argumentação jurídica não aniquila a subjetividade; mantem-na sob controle crítico.
O que deve ficar claro é que não se pode tolerar, num Estado Democrático de Direito, uma "justificação" que, a pretexto de fundamentar uma interpretação, termine por encobri-la. Ora, fundamentar é justamente proporcionar acesso interpessoal às razões que motivaram determinada decisão de interpretação. Esse esclarecimento é possível de ser feito; e deve ser levado a cabo não só pelo Poder Judiciário, mas também pela doutrina. Fundamentar é, pois, como levar alguém para um passeio informando-lhe o ponto de partida e o de chegada, o veículo de transporte e as razões da viagem. Deixar de informar o passageiro a respeito disso é fazer aquilo que os seqüestradores fizeram com Maruja, personagem do romance de GABRIEL GARCÍA MARQUES: "No se veía ninguna luz A Maruja le cubrieron la cabeza con una chaqueta y la hicieron salir agachada, de modo que lo único que veía eran sus propios pies avanzando, primero a través de un patio, y luego tal vez por una cocina de baldosines". 8

\section{Os Danos à Pessoa no Direito Brasileiro e a Natureza da sua Reparação}

\author{
Gudith Martins-Costa \\ Doutora em Direito Universidade de São Paulo.
}

Professora Adjunta de Direito Civil e de Teoria Geral do Direito Privado na Faculdade de Direito da Universidade Federal do Rio Grande do Sul .

"Para argumentar não basta, com efeito, possuir toda a sua razão; é preciso ver-se coagido a usála. O pensamento é nosso; mas a inspiraçầo vem de outro lugar. Tu falas, logo eu penso". ALAIN FINKIELKRAUT, A INGRATIDÃO

\begin{tabular}{|l|}
\hline \multicolumn{1}{|c|}{ SUMÁRIO } \\
Introdução. \\
I- Os Danos à Pessoa como Espécies de \\
Danos Extrapatrimoniais. \\
A. Classificação dos danos à pessoa; \\
B. A Relação entre os Danos à Pessoa e \\
o Dano Moral; \\
II - A Satisfação dos Danos à Pessoa. \\
A. A liquidação; \\
B. O Caráter da Condenação: rumo à \\
pena privada?
\end{tabular}

\section{INTRODUÇÃO}

If idéia de dano está no centro do instituto da responsabilidade civil, ligando-se muito proximamente ao valor que historicamente é dado à pessoa e às suas relações com os demais bens da vida. Se o mais relevante for a relação entre a pessoa e os bens patrimoniais, economicamente avaliáveis, cresce em importância a responsabilidade patrimonial, na qual a pessoa é vista tão só como sujeito titular de um patrimônio que, tendo sido lesado por outrem, deve ser recomposto. Se, ao contrário, em primeiro plano está a pessoa humana valorada por si só, pelo exclusivo fato de ser pessoa - isto é, a pessoa em sua irredutivel

1 Texto apresentado no Colloquio Internazionale L'Unificazione del Diritto in America Latina: Principi e Regole Comuni in Materia di Responsabilità Extracontrattuale, Roma, junho de 2000 e que integra Grupo de Pesquisa bases para a Unificação do Direito Privado no MERCOSUL coordenado pela autora. Agradeço à acadêmica de Direito Ana Lúcia Aguiar, bolsista do CNPq-PIBIC sob minha orientação, o auxílio na coleta dos subsídios jurisprudenciais e na revisão das notas.

Revista da Faculdade de Direito da UFRGS, v. 19, Março/2001
${ }^{8}$ GADAMER, Hans-Georg. "Vom Wort zum Begriff. Die Aufgabe der Hermeneutik als Philosophie". In: Die Moderne und die Grenze der Vergegenständlichung. Org. Bernd Klüser. München: Bernd Klüser, 1996. p. 30.

Revista da Faculdade de Direito da UFRGS, v. 19, Março/2001 
subjetividade e dignidade, dotada de personalidade singular e por isto mesmo titular de atributos e de interesses não mensuráveis economicamente - passa o Direito a construir princípios e regras que visam tutelar essa dimensão existencial, surgindo, assim, a responsabilidade extrapatrimonial.

Por esta razão, e, aliás, como tudo no Direito, o conceito de dano não é "dado", mas um "construído" ${ }^{2}$ e, maiś ainda, é, para usar uma expressão cara aos existencialistas, um "conceito situado". De uma perspectiva claramente nominalista - vale dizer, dano seria tão só prejuízo sofrido por um bem determinado, cal culado segundo a "Teoria da Diferença" alcança uma noção normativa, ou jurídica, pela qual o dano é a lesão a interesse jurídico ${ }^{4} . \mathrm{E}$ que é "interesse jurídico" é sempre aquilo que determinada comunidade considera digno de tutela jurídica, razão pela qual, se modificado o que, na pessoa e em sua personalidade cons dera-se digno de interesse, haverá imediato reflexo no conceito de dano.

Será que, no século XIX, quando era paradigma dominante $o$ homem produtor de riquezas materiais que animou o sonho burguês oitocentista - e fez das regras tutelares de seu patrimônio a dimensão privilegiada da própria personalidade - faria sentido falar em danos nãopatrimoniais? Antes de a psicanálise instaurar o seu reinado, pondo a nu a relevância da saúde psíquica e da vida sexual e afetiva, poder-se-ia cogitar da hipótese de "dano psíquico", "dano

à vida afetiva", "dano à vida conjugal", ou em "dano à realização sexual"? Anteriormente ao desmedido império das técnicas e dos meios de comunicação, inclusive a Internet, haveria como imaginar certos danos à vida privada e à intimidade? Antes dos avanços da genética, poder-sea pensar em danos decorrentes de manipulação celular em embriōes?

Parece pois conveniente, para que melhor se possa compreender a idéia de "responsabilidade por danos à pessoa", acentuar a indiscutivel importância que adquire hoje, nos mais diferentes ordenamentos jurídicos, a reconstrução do conceito de pessoa, reconstrução à qual está ligada a própria compreensão do que é o Direito Privado, levando-se em conta, na perspectiva de análise, não só o direito brasileiro, mas, por igual, o argentino. Ambos têm como pontos de encontro a comum base romanística e o fato de se terem aberto, ainda recentemente, à experiência democrática, o que os leva necessariamente a recompor os fundamentos axiológicos da idéia de pessoa como centro do sistema de princípios, direitos e garantias fundamentais e, por via de conseqüência, de todo o sistema jurídico.

A opção pela sincronia não deve, contudo, fazer esquecer a diacronia: a experiência histórica indica que a caracterização dos danos à pessoa e a sua própria ti pologia conformam modelo aberto, cujo conteúdo é preenchido jurisprudencialmente ${ }^{5}$, razão pela qual o concreto desenho do modelo está na dependência

2 Daí a distinção entre o conceito leigo, ou naturalista, de dano e ó conceito normativo, ou jurídico, de dano indenizável.

3 Segundo a qual o dano é a diferença entre a situação patrimonial antes e depois da ocorrência do prejuízo. Para estas observações vide CLÓVIS DO COUTO E SILVA, O conceito de dano no Direito brasileiro e comparado, in "O Direito Privado Brasileiro na visão de Clóvis do Couto e Silva", ao cuidado de VERA comparado, in "O Direito Privado Brasileiro na visão de Clóvis do Co

+ Veja-se Clóvis do Couto e Silva, op. cit., e Sérgio Viana Severo, "Os danos Extrapatrimoniais", Ed. Saraiva, $1996, p .6$ e ss.

5 Utilizo a categorização proposta às fontes do Direito por MIGUEL REALE, in "Fontes e Modelos do Direito - para um novo paradigma hermenêutico" Ed. Saraiva, São Paulo, 1994.

Revista da Faculdade de Direito da UFRGS, v. 19, Março/2001 da idéia de "pessoa humana" acolhida, no tempo histórico, por cada comunidade.

Como já tive a oportunidade de ano$\operatorname{tar}^{6}$, vivíamos, até há pouco, dominados pela idéia de pessoa modulada pela er codificatória, assim entendida a que seguiu-se às grandes codificações oitocentistas correspondentes à ascensão do individualismo burguês e do capitalismo. Aí foi desenhada a idéia de pessoa como "sujeito" e como "indivíduo".

O discurso jurídico é sempre um discurso conotado ${ }^{7}$ e, por recorrências lexicais diversas, seu dicionário é de certa forma, autôno$\mathrm{mo}^{8}$. Pessoa, Sujeito, Personalidade são palavras que têm diversas conotações no tempo e no espaço ${ }^{9}$. No discurso pandectista do século XIX, a palavra "sujeito" depreendeu-se das sub jetividades que mais tarde a psicanálise viria re-

velar e conotou-se a uma idéia externa, objetivada, por assim dizer, a idéia de um "sujeito" que é visto tão só como "termo" ou "elemento" da relação jurídica, como aquele que pode (é capaz de) ser titular de direitos, atuando na ordem jurídica. Sujeito que é privilegiadamente o "indivíduo", porque não mais definido pela pertença a um grupo, casta, classe, família, status, porque apartado (dividido) de um todo, de uma comunidade que o ultrapas$\mathrm{sa}^{10}:$ significaçōes reveladoras da "lógica proprietária" ${ }^{11}$ que revestiu a própria idéia de pessoa humana.

Submergida a idéia de "pessoa" na de "indivíduo" (ao senso "egoísta" do termo) e nãovisualizada a de "personalidade" pela preeminência do conceito técnico de "capacidade", traçaram-se as tramas semânticas que acabaram por fundir o "ser pessoa" com o "ser capaz de

6 In "O Princípio da Dignidacie da Pessoa e a Bioética: rumo ao Biodireito", Revista da Faculdade de Direito da UFRGS, 18, Porto Alegre, 2000.

7 A expressão é de AJ. GREIMAS, emSemiótica e Ciências Sociais, tradução de A/varo Lorencini e Sandra Nitrini, Ed. Cultrix, São Paulo, 1981, 75 ss.

\& AJ. GREIMAS, Semiótica e Ciências Sociais, cit., 76.

9 Como sintetiza com precisão MAREN TABORDA, com base na lição de Riccardo Orestano (in "IIProblema delle persone giuridiche" in Diritto Romano. Turim: Giappichelli, 1968), "ho Direito Romano antigo, a palavra 'pessoa' tinha o significado normal de 'homem', sem qualquer alusão à sua capacidade. Embora largamente empregado, o termo persona não tinha um valor técnico, e tanto era 'pessoa' o homem livre largamente empregado, o termo persona não tinha um valor técnico, e tanto era 'pessoa' o homem livre
quanto o escravo - persona servi -, ainda que este não fosse considerado sujeito de direito. Para o ser sujeito quanto o escravo - persona servi -, ainda que este não fosse considerado sujeito de direito. Para o ser sujeito de direito, além da condição 'ser homem', concorriam mais três, a saber: ser livre, cidadão e senhor de sí
mesmo - sui iuris. Só nos textos pós-clássicos é que emerge um emprego diverso do termo, para exprimir mesmo - sui iuris. Só nos textos pós-clássicos é que emerge um emprego diverso do termo, para exprimir entre o "ser humano" $o$ " ser pessoa" continuou na compilaşâo justinianéia e - recorro ainda a Maren Taborda - "os glosadores civilistas bolonheses continuaram a não lhe atribuir, em referência ao homem qualquer particular signifcacão juridica sendo apenas na canonistica mais precisamente na obra de Sinibaldo de Fieschi (futuro papa Inocencio IV), que se passou a aplicar correntemente o termo persona para designa entidades coletivas com uma configuração unitária e abstrata distinta de seus membros particulares". A
Publicização da noção de pessoa jurídica como fator de construçãa da dogmática do "Estado de Direito", Publicização da noção de pes
inédito. Porto Alegre, 2000).

10 Da literatura, mais do que dos tratados jurídicos, vem esta compreensão. Lembro, a propósito, de "Au plaisir de Dieu", o romance de JEAND'ORMESSON (Gallimard, Paris, 1974).

"I A expressão é de DA VIDE MESSINETTI, "Personalitá" (Diritti della), verbete, in Enciclopedia Giuridica Giuffrè, Milão, 1984, 356.

Revista da Faculdade de Direito da UFRGS, v. 19, Março/200 
adquirir direitos e contrair obrigações". Em outras palavras, instrumentalizou-se a personalidade humana, reproduziu-se, na sua conceituação, a lógica do mercado, o que conduziu à desvalorização existencial da idéia jurídica de pessoa, para torná-la mero instrumento da técnica do Direito ${ }^{12}$, ponto que foi percebido com especial nitidez pela civilista argentina Aida Kemelmajer de Carlucci segundo a qual, sob a ótica codificatória oitocentista o dano ("el mal hecho) à pessoa se justificava "en la supuesta existencia de un verdadero derecho del sujeto sobre el próprio cuerpo, concebido a imagen y semejanza del derecho de Propiedad"13. A frase "eu sou dono de meu corpo" expressa lapidarmente esta lógica. $O$ corpo humano, reificado, é visto como objeto d e um direito $\mathrm{d}$ e propriedade, integrante de um patrimônio individual, e, como os demais bens patrimoniais, pode ser objeto de mercancia ${ }^{14}$.

A barbárie do século XX - o totalitarismo estatal ${ }^{15}$, econômico ou científico ${ }^{16}-$ teve

como contrapartida a afirmação do valor da pessoa como titular da sua própria esfera de personalidade, a qual, antes de ser vista como mero suposto do conceito técnico de capacidade, fundamenta-se no reconhecimento da dignidade própria à pessoa humana. Esta é a "novidade" que tem, para o Direito, o princípio da dignidade da pessoa. Como explica Bernard Edelman ${ }^{17}$, embora a palavra "dignidade" fosse há muito conhecida, e a idéia de uma dignidade própria ao homem remonte à filosofia de Kant, a idéia da existência de uma proteção jurídica que é devida em razão da dignidade liga-se fundamentalmente a um duplo fenômeno, a barbárie nazista (que fez alcançar a idéia de crimes contra a humanidade, no Tribunal de Nuremberg) e à biomedicina.

Por este caminho opera-se um câmbio semântico específico, verifica-se a passagem de um grau de significação a outro: a dignidade da pessoa, como princípio jurídico, vai designar não apenas o "ser da pessoa", mas a "humani-

12 Veja-se as observações de HANS HATTENHAUER, "Conceptos Fundamentales del Derecho Civil", tradução espanhola de Pablo Salvador Coderch, demonstrando as razóes pelas quais desde Kant ter assentado na "Metafisica dos Costumes" que "pessoa é o sujeito cujos atos podem ser a si próprio imputados" operouse a transmutação da idéia de "pessoa" para a de "sujeito", abrindo caminho para a consideração da pessoa como "mero material para a construçẫo de relaçôes jurídicas", reduzindo-se a idéia de personalidade à noçẫo de "capacidade de direito". Na doutrina brasileira veja-se ALEXANDRE DOS SANTOS CUNHA "Di nid "

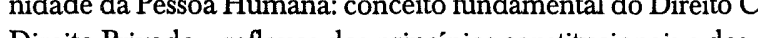
Direito Privado - reflexos dos princípios constitucionais e dos direitos fundi cuidado de JUDITH MARTINS COSTA, no prelo.

13 "Codigo Civil y leyes complementarias. Comentado, anotado y concordado", ao cuidade de BELLUSCIO YZANNONI, Astra, Buenos Aires, 1984, p. 34, comentário ao art. 68, apud J. MOSSET ITURRASPE, " El danõ fundado en la dimension del hombre", in Revista de Derecho Privado y Comunitario, 1, 1995, 34

It Veja-se o instigante texto de MARIE-ANGĖLE HERMITE, "Le corps hors du commerce, hors du marché", in Archives de Philosophie du Droit, T. 33, 323 e ss., na qual propõe a categorização das "coisas de origem humana" como escapatótia à lógica do mercado para a apreciação daquilo que, no corpo, pode ser objeto de relaçâo jurídica (sangue, órgãos, etc).

15 Acerca dos vários totalitarismos, notadamente o político, veja-se CELSO LAFER, "A Reconstrução dos Direitos Humanos - um diálogo com o pensamento de Hannah Arendt”, São Paulo, Ed. Companhia das Letras, 1991.

16 Acerca do totalitarismo da ciência veja-se BERNARD EDELMAN, "Sujet de droit et technoscience", in La personne en danger, Ed. PUF, 1999, 397.

17 "La dignité de la personne humaine, un concept nouveau", in La personne en danger, Ed. PUF, 1999, 505

Revista da Faculdade de Direito da UFRGS, v. 19, Março/2001 dade da pessoa" ${ }^{18}$. Esta é vista de uma perspectiva que não a confunde conceitualmente com o "sujeito capaz juridicamente", nem com o indivíduo atomísticamente considerado, significando, diversamente, "a reunião simbólica de todos os homens naquilo que eles têm em comum, a saber, a sua qualidade de seres humanos. Em outras palavras, é ela que permite o reconhecimento de uma pertença (appartenance) a um mesmo "gênero": o gênero humano" ${ }^{19}$. A mudança de grau no significado está em que a dignidade é o atributo ou qualidade desta pertença: "se todos os seres humanos compõem a humanidade é porque todos eles têm esta mesma qualidade de dignidade no "plano" da humanidade; dizemos que eles são todos humanos e dignos de o ser ${ }^{\prime 20}$.

Por isto é que, mais do que uma "vazia expressão", como poderiam pensar os que estão ainda aferrados à concepção legalista estrita do ordenamento jurídico, a afirmação do princípio, que nos mais diferentes países tem sido visto como um princípio estruturante da ordem constitucional - apontando-se-lhe inclusive um valor "refundante" da inteira disci plina priva$\mathrm{da}^{21}$ - significa que a personalidade humana não é redutível, nem mesmo por ficção jurídica, apenas à sua esfera patrimonial, possuindo dimensão existencial valorada juridicamente na medida em que a pessoa, considerada em si e em (por) sua humanidade, constitui o "valor fonte" que anima e justifica a própria existência de um ordenamento jurídico.

É o que assinala o civilista peruano Carlos Fernandez Sessariego, pioneiro na América Latina no destacar a proteção jurídica a pessoa humana: "Referirse a la protección de la persona humana supone, como cuestión previa, determinar que tipo de ente es ella, considerada en si misma, per se. Es decir, indagar por la naturaleza misma del ser sometido a protección jurídica", pois é "la necesaria aproximación a la calidad ontológica del bien a tutelar (que) nos permitira precisar tanto los criterios como la técnica jurídica susceptibles de utilizar para lograr este primordial objetivo" ${ }^{\text {22 }}$. Ou como entre nós afirmou recentemente Josaphat Marinho ao aludir à disciplina dos direitos da personalidade, " $o$ homem, por suas qualidades essenciais, e não propriamente o dado econòmico, torna-se $o$ centro da ordem jurídica" ${ }^{23}$.

No que concerne especificamente ao Direito Civil o princípio da dignidade da pessoa humana tem permitido a reconstrução conceitual do termo "pessoa" ${ }^{24}$ em larga medi-

18 "La dignité de la personne humaine, un concept nouveau" cit, 507.

19 "La dignité de la personne humaine, un concept nouveau" cit, 509, traduzi.

s "La dignité de la personne humaine, un concept nouveau" cit, 509, traduzi 2t Na literatura italiana, PIETRO PERLINGIERE, "Il Diritto Civile nella Legalità Constituzionale" e na
literatura brasileira, o artigo pioneiro de MARLA CELINA BODIN DE MORAES, "A caminho de um Direito Civil Constitucional", in Revista Direito, Estado e Sociedade, PUC, $n^{\circ} 1$, Rio de Janeiro, 1991 e a monografia de TERESA NEGREIROS, "Fundamentos para uma interpretação constitucional do princípio da boa-fé", Ed. Renovar, 1998

2 "Protección a la persona humana", in Revista Ajuris, 56, Porto Alegre, 1992, 87 e 88

23 "Os Direitos de Personalidade no Projeto do Novo Código Civil Brasileiro", in Boletim da Faculdade de Direito da Universidade de Coimbra, col. Stvdia Ivridica, 40, in Portugal-Brasil ano 2000, Coimbra, 2000.

${ }^{24}$ Para o exame da concretização jurisprudencial do princípio e suas repercussões, BERNARD EDELMAN, "La dignité de la personne humaine, un concept nouveau", in "La personne en danger", cit, 505 e ss. 
da com base no fato de as "Constituições do Século XX"25 o terem posto - ou deixado suposto - como princípio estruturante da ordem constitucional. É indiscutível que a atual ênfase numa esfera de valores existenciais da pessoa deve-se, entre outros fatores ${ }^{26}$, à compreensão do papel desempenhado pelos princípios constitucionais no Direito Civil na medida em que estes, para além de constituírem normas jurídicas atuantes nas relações de Direito Público, têm incidência especial em todo o ordenamento e, nesta perspectiva, também no Direito Civil, disciplina das relações jurídicas travadas entre os particulares entre $\mathrm{si}^{27}$. Ao mesmo tempo, estando estes princípios e garantias expressos em cláusulas gerais ${ }^{28}$, permite-se 0 desenvolvimento jurisprudencial de novas hi póteses mediante a emprego do raciocínio tópico, podendo-se assim falar na elaboração de um direito geral da personalidade que não se esgoa no reconhecimento dos tradicionais atributos, tais como a honra, o nome, a imagem, a

intimidade e a vida privada, mas tem alargada possibilidade de expansão.

Pela via aberta por estas novas configuraçōes semânticas e metodológicas a contemporânea afirmação da dignidade da pessoa humana superou as delimitações individualistas e puramente formais que poderiam tê-la marcado no individualismo burgu ês, passando a constituir, como observa Maurício Ribeiro Lopes, "um ponto de apoio fundamental da defesa dos direitos humanos, sob o prisma da igualdade material ${ }^{29}$ Abre-se, assim, vasto e rico campo de reconstrução de institutos e conceitos no Direito Privado, entre os quais o de responsabilidade civil, o adjetivo ligando-se menos à disci plina consagrada pelo paradigma oitocentista da sociedade burguesa e mai às suas raízes etimológicas, indicativas de quem está na cive, e, sendo assim, vive em necessária comunidade.

${ }_{25}$ Uso essa expressão para deixar marcada a distinção entre as Constituições posteriores ao pós-guerra europeu $e$ as "Constituiçôes do Século XIX", uma e outra expressão não devendo ser lidas em sua literalidade cronológica, mas com pela primeiro tem-se a Constituição como documento meramente político, formado pelas normas de organização da estrutura e das funçôes do Estado e dos seus Poderes; o segundo modelo indica a Constituição normativa, fundada em normas (princípios e regras) cujo conteúdo material em muito ultrapassa a mera regulação da organização estatal.

2 Assim a Filosofia existencialista, na qual o ser humano concreto, porque marcado por sua dimensão histórica está no centro do debate filosófico, a Psicologia e a Psicanálise e, fundamentalmente, a Ética.

2 Como referência a esta vasta questão, consulte-se PIETRO PEILINGIERE, "ql Diritto Civile nella legalità costituzionale", cit, JOAQUIN ARCE Y FLORES-VALDEZ, "El Derecho Civil Constitucional", Editoria Civitas, $1^{\underline{a}}$ ed. Madrid, 1986; KONRAD HESSE, "Derecho Constitucional y Derecho Privado", Editorial Civitas, $1^{2}$ ed., Madrid, 1985. Na literatura brasileira, MARIA CELINA BODINDE MORAES e TERESA NEGREIROS, antes citadas e LUÍS AFONSO HECK, "Direitos Fundamentais e sua influência no Direito Civil", in Revista da Faculdade de Direito da UFRGS Ed. Síntese, 8, Porto Alegre, 1999, 111-125.

2s Para o conceito de cláusula geral vide o meu "A Boa Fé no Direito Privado", Editora Revista dos Tribunais, 1999, 273 a 377.

2 "A dignidade da pessoa humana: estudo de um caso", Revista dos Tribunais $758 / 107$ e ss. O trecho transcrito está na p. 113, e o "caso" examinado constitui um dos mais lúcidos momentos da jurisprudência brasileira que pela inteligência do Desembargador Relator, Cezar Peluso conferiu eficácia direta e imediata ao princípio para o efeito de afastar regras do Código Civil com ele colidentes (TJSC-Ap. Civ. $n^{\varrho} 007.512-4 / 2-00-2^{a}$ Câm. - j. 18.08.1999).

Revista da Faculdade de Direito da UFRGS, v. 19, Março/2001
É sob esta perspectiva da renovação e reconstrução conceitual que enfoco o tema da reparação civil dos danos à pessoa, começando por questionar a apontada autonomia da fattispecie ou sua compatibilidade com o regime incidente à tutela do dano moral (I), para alcançar, após, o exame dos critérios da liquidação e a natureza da reparação (II).

I - OS DANOS À PESSOA COMO ESPÉCIES DE DANOS EXTRAPATRIMONIAIS

Integram e concretizam a dignidade humana, no campo da responsabilidade civil, interesses tais como a vida privada ${ }^{30}$, a intimida$\mathrm{de}^{31}$ ou o "direito de estar só, consigo mesmo", a dor ${ }^{32}$ e os afetos, as expectativas de vida e os projetos existenciais, a imagem social e a autoestima, a estética, as criações do intelecto em seus aspectos não-patrimoniais, a honra e o nome, interesses constitucionalmente garantidos e que

Têm crescido no Brasil os casos judiciais que buscam demarcar os limites entre a tutela à vida privada $e$ a liberdade de imprensa. Exemplificativo é acórdão da $7^{a}$ Câmara Civel do TJRGS na Ap. Civ. no 595098856, Rel. Des. Paulo Heerdt, 25. 10. 95, assim ementado: "Liberdade de Imprensa. Limites. Direito Constitucional á Reserva da Intimidade. Direito do Cidadâo a Privacidade. A liberdade de imprensa, embora essencial nal á Reserva da Intimidade. Direito do Cidadâo à Privacidade. A Liberdade de imprensa, embora essencial Federal, que assegura a intimidade e a privacidade dos cidadãos. (...)".

3 Exemplificativamente, acórdão da $4^{a}$ C. Civ. do TJRGS na Ap. Civ. no 59516596, Rel. Des. Ramon Georg von Berg, 08.11.95, cuja ementa é a que segue: "Tutela Civil da intimidade. Estabelecimento Bancário. Fornecimento de Extrato a terceiro. Dano Moral Configurado. A devassa da intimidade dos correntistas, que tiveram o extrato de sua conta corrente que mantinham com o demandado entregue a terceiro com o qual tiveram o extrato de sua conta corrente que mantinham com o demandado
litigavam, constitui dano moral. Aplicaçấo do inciso $X$, do art. $5^{\circ}$ da $C F . "$

32 Assim o caso, julgado pelo TJRGS, pelo qual condenou-se solidariamente médico, hospital e banco de sangue ao pagamento de indenização por dano material e moral a paciente pela divulgacão do resultado de exame para identificar o vírus da SWA, decorrendo o dano extrapatrimonial tanto da quebra do dever de sigilo, com prejuí a imagem, quanto da quebra do dever de refar o exame, que não era defnitivo eque uma vez refeito, veio a confirmar que o paciente não era portador do vírus HIV. Por esta lesão, da qual decorreu o sentimento de dor e medo de morrer, eis que lhe fora comunicado pelo médico que teria "ho máximo três meses de vida" decorreu o dever reparatório. (Ap. Civ. no 595160250, Rel. Des. Araken de Assis, j. 7.12.95, in RJTJRGS $n^{\circ} 175 / 702$ ).

33 "Protección a la persona humana", cit., 115.

34 "Protección a la persona humana", cit., 121. suscitar o caos: frente ao crescimento das espé constitutivos de uma classificação própria ou podem ser sistematicamente reconduzidos ao se do seu regime?

em construção. Numa definição meramente aproximativa, Sessariego ${ }^{33}$ os delineia como os humano considerado em sua integridade o que, em outros ordenamentos, como o italiano e o francês, têm sido caracterizado como dano biológico", "dano à saúde", "dano ao projeto de vida" e o "dano moral", considerado em seu aspecto estrito ${ }^{34}$. Podem tem origem servem a renovar o antiquíssimo instituto da resdem humanamente elaborada, pode por vezes, 
contratual ou extracontratual e, embora qualificados como danos extrapatrimoniais, pois atingem a pessoa em sua esfera de humanidade não raro têm origem em evento que pode ter reflexos também na esfera patrimonial ${ }^{35}$, o que caracteriza a chamada cumulação objetiva ${ }^{36}$.

Cabe à Itália a distinção de ter sido o primeiro país a sistematizar, no Código Civil, os direitos de personalidade ${ }^{37} \mathrm{e}$ à sua doutrina honra de cunhar a expressão "danos à pessoa", por obra de Guido Gentile, em $1962^{38}$. Desde então, discute-se se estes configuram ou não um "tertium genus" ou se estão compreendidos na categoria do dano moral. Debate-se, ainda, se esta expressão guarda ou não sinonímia com a expressão "dano extrapatrimonial", utilizada prevalentemente na literatura germânica ${ }^{39}$.

É bem verdade que o desenvolvimento

das expressões "dano à pessoa", "dano à saúde" e "dano biológico" deveu-se, na doutrina na jurisprudência italianas, à necessidade de utrapassar a "norma de clausura" do art 2059 do Codice Civile segundo o qual a responsabilidade não-patrimonial é admitida "solo nei casi determinati dalla legge", admitindo-se, assim, a indenizabilidade somente quando o dano seja conseqüência de um fato que tipifique um crime $\mathrm{e}^{40}$.

Em razão desta limitação, doutrina e tribunais encontraram na norma do art. 32 const tucional, que situa a saúde como "fondamentale diritto dell "individuo e interesse della collettività" a janela que permitiu a formação, por via jurisprudencial, de uma nova fattispecie, a saber, o "dano biológico", tido como uma concha hospedeira de quase todos os danos extrapatrimoniais que estivessem conexos a qualquer lesão ao bem jurídico "saúde", entendido

${ }^{35}$ Assim, o sempre lembrado exemplo de um acidente automobilistico no qual uma artista de cinema vem a lesionar gravemente sua saúde, perdendo a beleza fisica ou certos atributos funcionais. O dano será patrimonial na medida em que o acidente e os seus efeitos infletem sobre o patrimônio da vítima, mas haverá também dano não patrimonial, por atentado ao "projeto de vida", ou "dano psíquico" (conforme a qualificação dada pela doutrina dos diferentes países) na medida em que a carreira projetada, na qual a pessoa pretendia desenvolver a sua personalidade como artista, restará impossibilitada. Pode ser lembrada a hipótese de homossexual que, por ter a sua imagem devassada por meio de comunicacão que revel, com escandh a

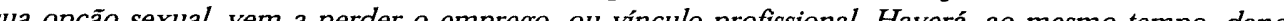
sua opsao sexul, vem a perder o enprego, ou vorculo profissonal Havera, ao mesmo ienpo, dano patrimonial, pela perda do vínculo profissional e dano extrapatrimonial, seja por violaçâo da imagem, seja pelo atentado ao livre desenvolvimento da personalidade.

36 Consagrada, no Direito Brasileiro, pela Súmula 37 do Superior Tribunal de Justiça, pela qual "são cumuláveis as indenizações por dano material e moral oriundos do mesmo fato".

${ }^{37}$ Codice Civile, Livro I, Titulo I, arts. $5^{\circ}$ a 10.

* A primazia é atribuída porJORGE MOSSETITURRASPE, "El danõ fundado en la dimension del hombre", in Revista de Derecho Privado y Comunitario, cit, 16. A expressão foi usada por GENTILE no verbete "Danno a la persona" da Enciclopedia del Diritto, Milāo, Tomo VI,. 634 e ss.

* Para o exame do estado atual da discussão consultei VICENZO CARBONE (coord), Responsabilità Civile - rassegna di Giurisprudenza e Dottrina, IPSOA, 1998, PAOLO CENDON, LUIGI GAUDINO e PATRICIA ZIVIZ, "Responsabilità Civile", Riv. Dir. Civ. anno LXV, no 3 , 1991, 971, MARCO BONA, "Danno alla persona", Riv. Dir. Civ., 313 e FRANCESCO DONATO BUSNELLI, "Interessi della persona e risarcimento del danno", Riv. Dir. Civ., $p$.

* Situação semelhante ocorre na Alemanha, em virtude da regra limitativa do parágrafo 254 do BGB, severamente criticada pelos tribunais, que alargaram o seu espectro, conforme dá conta CLÓVIS DO COUTOE $S I L V A$, in "Princi pes Fondamentaux de la Responsabilité Civile en Droit Brésilien et Comparé", 1988, datilografado, 60 .

Revista da Faculdade de Direito da UFRGS, v. 19, Març/2001 em seu mais amplo sentido, seja saúde física, seja o bem estar psíquico ou mental ${ }^{41}$.

As circunstâncias peculiares ao sistema italiano não devem confundir o comparatista, sendo por isto indevida a mera transposição conceitual, até porque não havendo, no Direito brasileiro vigente, limitação ao reconhecimento do dano moral e à formação de concretas fattispecies-sendo a matéria regulada por meio de cláusulas gerais - não há o repúdio à expressão "dano moral", tal como verificou-se no Direito italiano, que precisou ultrapassá-la para permitir a aceitação de novas hi póteses em um quadro mais efetivo de reparação. Assim, embora não seja tecnicamente a melhor expressão, como adiante examinarei, seu emprego vem legitimado pelo uso, podendo-se afirmar que, no Brasil, as expressões "dano moral" e "dano não-patrimonial” são sinônimas. Entendida latamente a expressão "dano moral", os "danos à pessoa" constituem uma de suas espécies.

No vigente Direito Brasileiro, as cláusulas gerais que regulam a responsabilidade civil extrapatrimonial encontram-se no art. $1^{\circ}$, inciso
III ${ }^{42}$ e no art. $5^{\circ}$, incisos $\mathrm{V}$ e X da Constituição Federal $^{43}$, no art. $6^{\circ}$, incisos VI e VII da Lei $\mathbf{n}^{\circ}$ 8.078, de 11.9.90 (Código de Defesa do Consumidor $^{44}$, no art. 17, combinado com o art. 201 incisos V, VIII e IX da Lei no 8.069, de 13.07.90 (Estatuto da Criança e do Adolescente ${ }^{45}$ ), e, ainda, no art. 1.553 do Código Civil, norma de abertura em matéria de fixação do quantum indenizatório. Se aquiliana a fonte do dever de indenizar incide, ainda, a cláusula geral do art. 159 do Código Civil, que estabelece os pressupostos da responsabilidade segundo o modelo posto no célebre art. 1382 do Código de Napoleão, limitando, contudo, o seu alcance pela redação aposta à sua segunda parte, mediante a qual "a violação da culpa e a avaliação da responsabilidade regulam-se pelo disposto neste Código, arts. 1518 a 1532 e 1537 a 1553".

Existem, demais disto, as fattispecies de dano extrapatrimonial casuisticamente previstas pelo Código Civil Brasileiro que, coerentemente com o espírito de sua época, havia previsto escassas hipóteses, consistentes basicamente na indenização em casos de homicídio (art. 1537) de ofensas à saúde ou à integridade física (art.

4 Para o exame dos casos singulares de responsabilidade extracontratual por danos à pessoa e danos biológicos, ver CARBONE - Rassegna di Giurisprudenza e Dottrina, cit, Parte Terza, 217 a 277. Para o exame da reversão atual deste entendimento, MARCO BONA, "Danno alla persona", cit., 313.

42 Art. 1.: "A República Federativa do Brasil, formada pela união indissolúvel dos Estados e Municípios e dos Distrito Federal, constitui-se em Estado Democrático de Direitos, e tem como fundamentos (...) - III - a dignidade da pessoa humana".

43 Art. 5: “Todos são iguais perante a lei, sem distinção de qualquer natureza, garantindo-se aos brasileiros e aos estrangeiros residentes no país a inviolabilidade do direito à vida, à liberdade, à igualdade, à segurança e a propriedade, nos termos seguintes (...) V - é assegurado o direito de resposta, proporcional ao agravo, além da indenizção por dano material, moral e à ima honra e a imagem das pessoas, assegurado o direito a indenização pelo dano material ou moral decorrente de sua violação".

" Os dispositivos asseguram, como "direito básico" do consumidor, a reparação dos danos patrimoniais e morais que Ihes tenham sido causados.

${ }^{45} O$ art. 17 afirma o "direito ao respeito", da criança e do adolescente, consistente na inviolabilidade de sua integridade fisica e moral, "abrangendo a preservação da imagem, da identidade, da autonomia, dos valores, idéias e crenças, dos espaços e objetos pessoais", assegurando os citados incisos do art. 201 a competência do Ministério Público para impetrar açôes visando a tutela dos seus direitos e interesses.

Revista da Faculdade de Direito da UFRGS, v. 19, Março/2001 
1538), injúria ou calúnia (art. 1.547), "desonra" sexual de mulher (art. 1548), demais casos de violência sexual (art.1.549) e por ofensas à liberdade (art. 1550). Leis especiais, como Lei $\mathrm{n}^{\mathrm{o}}$ 9.610, de 19.2.98 (Lei dos Direitos Autorais), contém enumeração casuística dos direitos extrapatrimoniais do autor ${ }^{46}$

$\mathrm{O}$ aspecto mais importante do sistema brasileiro reside, como observou Clóvis do Couto e Silva ${ }^{47}$, na conjugação de duas cláusulas gerais do Código Civil, a do art. 159, que dá as condiçōes para o nascimento do dever de indenizar, e a do art. 1553, segundo a qual "nos casos não previstos por este Capítulo, se fixará por arbitramento a indenização". Na opinião do autor - expressa ainda antes que a Constituição de 1988 encerrasse definitivamente a polêmica acerca do cabimento, ou não, do dano moral no direito brasileiro - "essa disposição não impede a indenização dos danos morais, $e$ ela constitui mesmo uma cláusula geral nesta matéria. De mais a mais, o art. 1.553 se relaciona com o princípio do art. 159 do Código Civil, que pode ser considerado como uma cláusula

46 Arts. 22 a 27.

47 "Principes Fondamentaux de la Responsabilité Civile en Droit Brésilien et Comparé", cit., 61, original no idioma francês, versão minha.

48 "Princi pes Fondamentaux de la Responsabilité Civile en Droit Brésilien et Comparé", cit., 61 e 62, original em francês, versão minha.

49 "Código Civil", T. I, p. 256, observaçôes ao art. 76.

\$D Deve ser sempre ressaltado o pioneiro e corajoso voto do Ministro Pedro Lessa ainda nos primeiros anos do século XX, orientação que, contudo, não foi seguida (STF, Ac. De 13.12.1913, transcrito na Revista dos Tribunais $n^{\circ} 8, p .180$.

${ }^{5 l}$ Para o exame dessa evolução, vide YUSSEF SAID CAHALI, "Dano Moral", $2^{a}$ edição, Ed. Revista dos Tribunais, 1998,43 a 51.

32. Trata-se aí do choque entre a liberdade empresarial, expressa na publicidade comercial e o tutela da dignidade da pessoa e dos direitos da personalidade, devendo a primeira ceder quando abusiva, encontrando-se os parâmetros que auxiliam a concrȩ̧ão desta expressão (" abusiva") no art. 37 , parágrafo $2^{\circ}$ do CDC: "Е́ abusiva, dentre outras, a publicidade discriminatória de qualquer natureza, a que incite à violência, explore o medo ou a superstição, se aproveite da deficiência de julgamento e experiência da criança, desrespeita valores ambientais, ou que seja capaz de induzir o consumidor a se comportar de forma prejudicial ou perigosa à sua saúde ou segurança".

Revista da Faculdade de Direito da UFRGS, v. 19, Março/2001
Mesmo após a Constituição, porém, poucos são os acórdãos que buscam no princípio da dignidade da pessoa humana a fonte para a criação de novos casos ${ }^{53}$, ou para operar a ponderação de valores quando conflitantes princípios e garantias constitucionais ${ }^{54}$, frente aos constantes atentados verificados, na ordem prática, ao livre desenvolvimento da personalidade e à dignidade humana.

Esta limitação, para além das razões metodológicas e sociológicas ligadas à formação da magistratura brasileira pode ter por base, também, as dificuldades advindas da pré-compreensão da expressão "dano moral" que, conotando a idéia de dor ou de pretium doloris, em certos casos é impeditiva de uma apreensão mais integral do fenômeno da personalidade humana, cuja dimensão é ao mesmo tempo subjetiva e social ${ }^{55}$.
Cabe, assim, examinar, à vista da doutrina e da jurisprudência brasileiras, as distinções conceituais, comparando-as com as observações doutrinárias e os preceitos legais verificáveis no Direito Argentino de reparação de danos.

B. Dano Moral e Dano à Pessoa: soluções do direito brasileiro e argentino

A legislação brasileira utiliza a expressão "dano moral" para referir-se a todas as espécies de danos não-patrimoniais, assim constando do art. $5^{\circ}$, incisos $\mathrm{V}$ e X da Constituição Federal, do art. 186 do Projeto do Código Civil, ora em tramitação final na Câmara dos Deputados e da legislação es pecial, antes referida. A mesma denominação é seguida por grande parte da doutrina $a^{56} \mathrm{e}$

33 Curiosamente, o chamado "Código de Auto-Regulamentação Públicitária - CONAR, regulamentação estatutária privada, sem força coercitiva jurídica em sentido proprio estabelece, no art. 19 que toda a atividade publicitária deve caracterizar-se pelo respeito à dignidade da pessoa humana, à intimidade, ao interesse social, às instituições e símbolos nacionais, às autoridades constituídas e ao núcleo familiar", regra qué completada pela do art 20. Peloqual "nelhum án que cens to do CONAR podem a seconsidearmos que que auxiliem ponderação judicial, ou abe micho formam modelos decorrentes da prática social constante e relterada (regras da boa prática ou dos usos publicitários).

Por isto é exemplar acórdão do TJSC, por voto do Des. Alcides Aguiar que, fundamentado diretamente no princípio constitucional da dignidade da pessoa, deferiu Mandado de Segurança para sustar programa de televisão que noticiara fato delituoso, envolvendo o autor da ação, assinalando-se o seguinte excerto da fundamentaçâo: "Diante de dois direitos fundamentais conflitantes, deve prevalecer aquele que defende um bem maior, e, no caso em discussão, este é o da dignidade da pessoa humana face à liberdade, indiscriminada da imprensa". (MS no 9.564, $4^{a}$ C. Civ. TJSC, Xanxerê, Rel. Designado Des. Alcides Aguiar, 13. 03. 97).

5 O que foi posto em evidência pelo Existencialismo, sendo tratado, em seus reflexos jurídicos, por CARLOS FERNANDEZ SESSARIEGO, "Protección a la persona humana", cit., 91 e ss.

so Assim, JOSÉ DE AGUIAR DIAS, "Da responsabilidade Civil", Ed. Forense, Rio de Janeiro, Tomo II, 1994, 713;

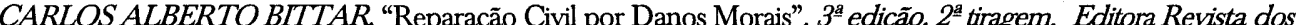

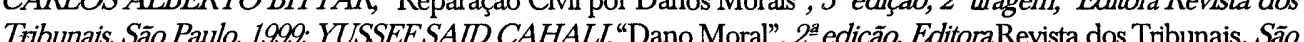
Tribunak, S O PU, Paulo, 198, CLOVIDO COUTO ESLVA, "O conceito de dano no Direito brasileiro e comparado", in "ODireito Privado Brasileiro na visa de Co Couto e Silva", ao cuidado de VERA FRADERA, Editora Livraria do Advogado, Porto Alegre, 19S7, 217, ARNOLDOMEDEIROS DA FONSECA, "Dano Moral", verbete in "Repertorio Enciclopédico Brasilero", Morais", Revista Forense 83/216, 1940, MARO MOACIR PORTO, "Algumas Anotaçoes sobre o Dano Moral", Revista Forense, 1159/492, MGUEL REALE, O Dano Moral no Direito Brasileiro, in Temas de Direito Positivo, Editora Revista dos Tribunais, São Paulo, 1992; WILSONMELODA SILVA, "O dano moral e sua reparação", Belo Horizonte, 1949, entre outros. 
da jurisprudência ${ }^{57}$, encontrando-se a distinção seja entre danos morais subjetivos e objetivos, seja entre danos morais diretos ou indiretos para especificar aqueles que dizem respeito diretamente à esfera da mais direta subjetividade e os que atinem à repercussão social da esfera da personalidade.

Raros são os textos, doutrinários ou jurisprudenciais, que utilizam a expressão "danos à pessoa" para indicar a vasta categoria dos atentados à personalidade, como o faz Clóvis do Couto e Silva ${ }^{58}$, o qual, todavia, realiza a sinonímia entre dano moral e dano extrapatrimonial ${ }^{59}$ que já havia sido contestada nos anos 60, com integral pertinência, por Pontes de Miranda ${ }^{60}$. Mais raros, ainda, são os julgados que traçam a distinção entre o "dano psíquico" e o "dano moral".

Em voto pioneiro ${ }^{61}$, proclamado mais de um lustro antes de a Constituição de 1988 ter assentado definitivamente a indenizabilidade do dano moral, o então Juiz do Tribunal de Alçada do Rio Grande do Sul Ruy Rosado de Aguiar Júnior, hoje Ministro do Superior Tribunal de Justiça acatou pedido de indenização, por "dano psíquico", de uma senhora, professora, grandemente prejudicada em seu físico, e até em seu pudor, em decorrência de lesões sofridas em acidentes de trânsito, o que motivou seu pedido de indenização, ao causador do dano, por invalidez parcial e permanente por dano estético e conseqüente cirurgia reparadora por danos psíquicos, se reconhecida a incapacidade total para o trabalho, e lucros cessantes.

A tese defendida por Rosado de Aguiar, vencida na $3^{\mathrm{a}}$ Câmara Cível, mas, posteriormen-

57 Exemplificativamente, na jurisprudência do Supremo Tribunal Federal, RExt 112263 (veiculação de programa sobre falecido jogador de futebol, sem autorização dos herdeiros); RExt 99501 (danos morais por modificação da obra e omissão do nome do autor); RExt 98942 (pensão e dano moral à companheira de vítima de acidente); RExt 83978 (não cabimento do dano moral à alegada vítima de dano por ricochete). Na jurisprudência do Superior Tribunal de Justiça, também exemplificativamente: REsp 221757 (publicação, jurisprudência do Superior Tribunal de Justiça, também exemplificativamente: REsp 221757 (publicação,
em revista especializada em "fofocas", de fotografia de jornalista, sem autorização); REsp 157912 (dano moral por ricochete); REsp 77117(responsabilidade de instituição bancária); Resp 60.033-2 (dano moral à pessoa jurídica, por ofensa à honra objetiva).

38 "O conceito de dano no Direito brasileiro e comparado", cit., 227.

37 "O conceito de dano no Direito brasileiro e comparado", cit., 230, como segue: Realizada a lesão ao direito de personalidade, e também a outros direitos e interesses, surge o problema da responsabilidade do dano extrapatrimonial, denominado, também, de dano moral".

क) Tratado de Direito Privado, T. 26, Ed. Borsoi, Rio de Janeiro, 1959, parágrafo 3.108, 30 e ss.

6t O Acórdão da $3^{\text {a }}$ Câmara Cível está comentado por AGUIAR DIAS in Revista Ajuris vol. 29m 1983, 65, sob o título "Dano psíquico e Dano Estético - uma decisão memorável". Na mesma Revista, a transcriçẫo do Acórdão que, acolhe em Embargos Infringentes ( $n^{\circ} 183001056$ - $2^{\circ}$ Grupo Cível - Novo Hamburgo, 25.03.1985) a argumentacão expendida no voto vencido, assentou, pelo voto do seu Relator, Juiz Décio Erpen, o que segue: "Acão de Reparação de Danos. Dano psíquico e dano estético, advindo de lesōes sofridas por prefor mesmo que a vítma passe a auferir proventos em razâo da profissão que desempenhava. Não há como se confundir o direito á indenização advindo de fato ilícito, com o de percepção de proventos, porque as relações jurídicas são diversas. Adoção dessa premissa com reservas de parte da minoria. $O$ direito deve proteger a pessoa com visão humanística, com seus predicados, atributos, atentando a um convivio futuro. Absorção do dano estético pelo psíquico acolhido pela maioria. Divergência nesse particular, entendendo-se cumuláveis em determinadas circunstâncias. Votos vencidos".

Revista da Faculdade de Direito da UFRGS, v. 19, Março/2001 te, acolhida pelo $2^{\underline{a}}$ Grupo Cível do mesmo Tribunal de Alçada por via de recurso de Apelação foi no sentido da indenizabilidade do dano psíquico, dada a sua qualificação como prejuízo no sentido jurídico do termo. O Relator do caso no $2^{\circ}$ Grupo Cível, Juiz Décio Erpen assentou, então, que o "direito deve proteger a pessoa com visão humanística, com seus predicados, atributos, atentando a um convívio futuro", em decisão tida pelo tratadista Aguiar Dias como "memorável". É de sublinhar o uso da expressão "dano psíquico", que demonstra a atenção do julgador à lição de Pontes de Miranda. Já na década de 50 acentuava este, com inteira razão, ter a expressão "dano moral" concorrido "para graves confusões", explicando:

"'As vezes, os escritores e juízes dissertadores empregam a expressão "dano moral" em sentido amplíssimo (dano à nor malidade da vida de relação, dano moral estrito, que é o dano à reputação, o dano por depressão ou exaltação psíquica ou nêurica, dano que não é qualquer dos an teriores mas também não ofende o patrimônio, como a dor sofrida, o de destruição de bem sem qualquer valor patrimonial ou de valor patrimonial ínfimo. Aí, dano moral seria dano não patrimonial. Outros têm como dano moral o dano à normalidade

da vida de relação, o dano que faz baixaro moral da pessoa e o dano à reputação. Finalmente, há o senso estrito de dano moral: o dano à reputação" 62 .

Contudo a distinção conceptual aí ensaiada não prosperou, o que veio a causar dificuldades quando se tratou de afirmar a indenizabilidade do dano extrapatrimonial às pessoas jurídicas - que não poderiam sentir a subjetividade da dor - tendo então, doutrina $e$ jurisprudência tendo que distinguir entre "honra objetiva" e "honra subjetiva" ${ }^{63}$.

Esta distinção tem origem, segundo o magistério de Miguel Reale ${ }^{64}$, em pioneiro ensaio de Renato Sconamiglio publicado, no ano de 1957, na Rivista di Diritto Civile, no qual observava que, "se o dano moral, como tal, se refere essencialmente à esfera subjetiva e íntima da personalidade, não se compreende como seja possível incluir nesta categoria um dano que, ao contrário, reverbera sobre relações externas ${ }^{755}$. Presente essa observação propõe Reale, seguido pela majoritária doutrina brasileira, a diferenciação entre dano moral objetivo, assim compreendido o que "atinge a dimensão moral da pessoa no meio social em que vive, envolvendo o de sua imagem", e o dano moral subjetivo, o qual estaria correlacionado "com o mal

29 Tratado de Direito Privado, T. 26, cit., 31, grifos do autor.

a3 Assim decisão do STJ no REsp nº6033-MG, Relator Ministro Ruy Rosado de Aguiar, in DJ 27.11.95; no mesmo sentido, REsp n 112127 - RS, Rel. Min. Bartos Monteiro e REsp no 129428 - RJ, Rel. Min. Ruy Rosado de Aguiar, o primeiro deles assim fundamentado: "Quando se trata de pessoa jurídica, o tema da ofensa à honra propõe uma distinção inicial: a honra subjetiva, inerente à pessoa física, que está no psiquismo de cada um e pode ser ofendida com atos que atinjam a sua dignidade, respeito próprio, auto-estima, etc., causadores de dor, humilhação, vexame; a honra objetiva, externa ao sujeito, que consiste no respeito, causadores de dor, humilhação, vexame; a honra objetiva, externa ao sujeito, que consiste no respeito, admiração, apreço, consideração que os outros dispensam à pessoa. (...) A pessoa jurídica, criação da ordem legal, não tem capacidade de sentir emoção e dor, estando por isso desprovida de honra subjetiva e imune à injúria. Pode padecer, porém, de ataque á honra objetiva, pois goza de uma reputação junto a terceiros, passível de ficar abalada por atos que afetam o seu bom nome no mundo civil ou comercial onde atua".

64 "O Dano Moral no Direito Brasileiro", cit., 22.

${ }^{65}$ RENATO SCONAMIGLIO, "Il dano morale" Contributo alla teoria del danno extracontrattuale, in Rivista di Diritto Civile, vol. 3, 1957, 283.

Revista da Faculdade de Direito da UFRGS, v. 19, Março/2001 
sofrido pela pessoa em sua subjetividade, em sua intimidade psíquica, sujeita a dor ou sofr do seu ser subjetivo, que o ato ilícito veio penosamente subverter, exigindo inequívoca re paração" ${ }^{\prime 66}$. Só assim explicar-se-ia, aliás, a de feituosa redaça do inciso $\mathrm{V}$ do art. $5^{\circ} \mathrm{da}$ Constituição brasileira, que trata da indenizabilidade do dano "material, moral ou à imagem", tomando-se "patrimonial" por "material" e tentan do-se desajeitadamente distinguir entre o chamado dano moral subjetivo e objetivo pelo emprego da alternativa "moral" e " à imagem", quando poderia tudo simplificar e melhor sistematizar com o emprego da expressão "extrapatrimonial". recente ${ }^{67}$ vozes que propõem a distinção conceitual não para caracterizar o dano à pessoa como um tertium genus, mas para assentar o emprego da expressão "danos extrapatrimoniais" como indicativa de gênero do qual seriam espécies os "danos à personalidade". Assim, Sérgio Vianna Severo, para o qual a importância dos direitos da personalidade não deve levar nem à construção de um terceiro gênero nem à redução de todos os danos extrapatrimoniais às lesões à personalidade porquanto "a proteção cível dos direitos de personalidade encontra-se inserida na esfera dos da nos extrapatrimoniais, é uma de suas espécies; não é, portanto, um gênero autônomo, nem, muito menos, a síntese dos interesses não eco porque ligados a valores

Por isto encontra-se na doutrina mais

nômicos juridicamente protegidos" $"$.

Entendo efetivamente que, sendo mais ampla, a expressão "danos extrapatrimoniais" inclui, como subespécie, os danos à pessoa, ou à personalidade, constituído pelos danos morais em sentido próprio (isto é, os que atingem a honra e a reputação), os danos à imagem, projeção social da personalidade, os danos à saúde, ou danos à integridade psicofísica, inclusos os "danos ao projeto de vida" $a^{69}$ ", e ao "livre desenvolvimento da personalidade", os danos à vida de relação, inclusive o "prejuízo de afeição" e os danos estéticos. Inclui, ainda, outros danos que não atingem o patrimônio nem a personalidade, como certos tipos de danos ambientais.

A distinção entre as várias subespécies de danos à pessoa justifica-se porque a expresão "dano moral", em virtude de suas próprias conotações históricas, está ligada à dor moral, ressentindo-se do entendimento que rejeitava a indenizabilidade do pretium doloris por ser este incomensurável e, nesta medida, irredutivel valores monetários. Esta conotação redutora tem impedido, a meu juízo, a adequada apreensão, pela jurisprudência, de novas fattispecies que poderiam ser mais livremente desenvolvidas não fossem as amarras pré-compreensivas, o que têm importância capital nesta matéria, pois a maior particularidade dos deveres extra-contratuais reside no fato de serem formados por criação jurisprudencial, pois eles não existem antes da

"O Dano Moral no Direito Brasileiro", cit, 23 Paulo, 1996.

\& Os Danos Extrapatrimoniais, cit, 47.

* Teria sido o caso de reconduzir-se a esta espécie decisão do Tribunal de Alçada do Rio Grande do Sul que "desimportante o fato de Diogo ter nascido apenas após o falecimento do pai", pois "mesmo que não o tenha conhecido, por certo terá o menino, por toda a vida, a dor de nunca ter conhecido o pai". (Ap. Civ. no
$195080585,5^{\mathrm{g}}$ C. Civ., 26.10.95, Rel. Des. Rui Portanova, in RTARGS 97/298).

Revista da Faculdade de Direito da UFRGS, v. 19, Março/200I
* Veja-se a monografia de SÉRGIO VIANA SEVERO, Os Danos Extrapatrimoniais, Editora Saraiva, São expressamente reconheceu "o direito" do nascituro à indenizaçâo pela morte de seu pai, considerando lesão, resultando, como afirmou Clóvis do Couto e Silva, de uma casuística feita pelos juizes por ocasião do julgamento, quando surge a questão de saber, in concreto, qual deveria ter sido o comportamento seguido pelo autor do dano ${ }^{70}$.

Demais disto, embora tradicional no Direito brasileiro, a expressão " dano moral" ressente-se, também, de armadilhas teóricas: seria indenizável, constituindo dano moral o atentado à honra de alguém, se este fato não provocasse, subjetivamente, nenhuma dor? Seria indenizável, sob o fundamento de constituir dano moral, o prejuízo à imagem, que diz respeito não à esfera do íntimo psiquismo, mas à dimensão da pessoa no meio social em que vive?

Não são estes os critérios, contudo, pelos quais modifica-se a linguagem e operam-se os câmbios semânticos: consagrada pelo uso a expressão "dano moral", é preciso enfrentar a "guerra de etiquetas" lembrada pelo Ministro se discutiu a possibilidade de cumulação entre dano moral e dano estético em razão de aciRuy Rosado de Aguiar Júnior em caso no qual dente no qual a vítima sofreu queimaduras graves, tendo amputadas braço e perna ${ }^{71}$. E a "multiplicidade de aspectos que a realidade apresenta" ao juiz continuará a ser perspectivada com a redutora expressão se aprovado o Projeto de Código Civil Brasileiro atualmente em tramitação no Congresso Nacional, muito embora a expressão "danos à pessoa" seja mais afinada com a tutela dos Direitos de Personalidade que o mesmo Projeto prevê e disciplina por meio da combinação de regras casuísticas e cláusulas gerais $^{72}$, sendo de anotar, entre estas, as do art. $12 \mathrm{e}$ a do art. 21 , a primeira configurando cláusula geral de tutela a todos os direitos de personalidade e voltando-se a segunda a garantir especificamente a vida privada da pessoa fisica, qualificadamente "inviolável"

$\mathrm{Na}$ doutrina latino-americana a decantação conceitual é apontada como necessária por Carlos Fernandez Sessarego, o qual afirma a necessidade de marcar a diferença existente entre "el concepto genérico de daño a la persona y la restringida noción de daño moral ${ }^{74}$, na medida em que o dano moral é apenas um dos to “Principes Fondamentaux ...", cit., 23

7 Resp 226190/RJ, Rel. Ministro Ruy Rosado de Aguiar Jr, STJ, 4. $4^{\underline{a}}$, in DJ 01.02.2000, unânime, sendo partes Milton Oliveira Rufino e Grêmio Recreativo Escola de Samba Beija Flor, em decisão assim fundamentada: Independentemente da nomenclatura aceita quanto ao dano extrapatrimonial, e sua classifcacão em dano moral, dano à pessoa, dano biológico, dano fisiológico, dano á sá́de, dano etc., cada um constituindo, com autonomia, uma espécie de dano, ou todos reunidos sob uma ou outra dessas denominações, a verdade é que para o juiz essa disputa que se põe no âmbito da doutrina, essa verdadeira "guerra de etiquetas" de que nos fala MOSSET ITURRASPE ("El daño fundado en la dimensión del hombre en su concreta realidad", Revista Derecho Privado y Comunitario, 19) somente interessa para evidenciar a multi plicidade de aspectos que a realidade lhe apresenta, a fim de melhor perceber como cada uma delas pode e deve ser adequadamente valorizada do ponto de vista juŕdico".

72 Acerca do emprego destas técnicas na Parte Geral do Projeto vejase o ensaio de JOSÉ CARLOSMOREIRA ALVES, "A Parte Geral do Projeto do Código Civil Brasileiro", Ed. Saraiva, 1986.

73 A previsão da reparabilidade do dano também encontra-se adequadamente posta na Parte Geral que comanda todo o sistema - estatuindo o art. 186, também redigido sob a forma de cláusula geral (e sem incorrer nas limitações que sofre $o$ art. 159 do vigente Código pela redaçấo aposta à sua parte final) a reparabilidade do dano, "ainda que exclusivamente moral", causado por ato ilicito e culposo.

74 Protección a la persona humana, in "Daño y protección a la persona humana, Andorno et alii, Ediciones la Roca, Buenos Aires, 1993, 57 
tantos componentes do amplo espectro de lesões compreendidas no genérico conceito de dano à pessoa. Na classificação que propõe, este abarca o dano moral como lesão "a uno de los múltiples aspectos o facetas de la personalidad" e o "dano ao projeto de vida", compreendendo todos os atos atentatórios ao livre desenvolvimento dos projetos existenciais e inclusive os danos à saúde, considerada a expressão em seu mais amplo espectro, "toda lesión que, en alguna medida o intensidad, afecta el bienestar del sujeto de derecho" 75

Diferentemente do que ocorre na doutrina brasileira, é crescente, na Argentina, o emprego das expressões "danos à pessoa" e "danos extrapatrimoniais". A primitiva redação do Código Civil Argentino não continha - nem poderia conter, já que editado em 1871 -, nenhuma menção aos direitos da personalidade ou aos danos a pessoa, embora previsse, em regra ainda vigente que "habrá daño siempre que se causare a otro algún perjuicio susceptible de apreciación pecuniaria, o directamente en las cosas de su dominio o posesión, o indirectamente por el mal hecho a su persona $o$ a sus derechos o facultades" (art. 1068).

Segundo Mosset Iturraspe ${ }^{76}$, a situação começou a mudar nos últimos trinta anos, e, no que diz com os danos extrapatrimoniais, especialmente a partir da reforma de 1968 que, nos artigos 522 e 1078, com a redação dada pela Ley 17.711 , aludiu ao dano moral, muito embora a doutrina seguisse, por algum tempo, ainda a concepção estreita do pretium doloris.

Compreende-se a inserção, na reforma de 1968, da expressa previsão da responsabilidade por dano moral, haja vista o perfil do seu redator, o civilista Guillermo Borda, cuja obra é marcada por profundo humanismo. Na redação que propôs, o dano à pessoa está no centro da responsabilidade determinando o art 522 caber ao juiz condenar "al responsable a $l$ reparación del agravio moral que hubiera causado, de acuerdo con la índole del hecho generador de la responsabilidad y circunstancias del caso", constituindo verdadeira cláusula geral na matéria. Já o caput do art. 1078 contém regra que firma o caráter de reparação, estatuindo que a obrigação de ressarcir o dano causado pelos atos ilicitos "comprende, además de la indemnización de pérdidas eintereses, la reparación del agravio moral ocasionado a la víctima".

$\mathrm{O}$ alcance das reformas de 68 foi ainda ampliado doutrinariamente, assinalando-se en tre os trabalhos elaborados as "Jornadas sobre temas de responsabilidad civil en caso de muerte o lesión de las personas", celebradas en Rosario em 1979 e o II Congreso Internacional de Derecho de Daños, celebrado em Buenos Aires em 1991, que afirmou a expressão "daño a la persona" e assentou, entre outras, as seguintes recomendaçōes:

"El daño a la persona configura un ámbito lesivo de honda significación y trascendencia en el que pueden generarse perjuicios morales y patrimoniales"; " El daño a la persona no constituye una categoría autónoma"; "la lesión a la persona sicofisica constituye un daño autónomo", "Corresponde ampliar el contenido del daño patrimonial y moral a fin de salvaguardar eficazmente la intangibilidad de la persona" "El dãno moral se extiende más allá de la afectación síquica”; " La reparación del dano a la persona debe ser plenamente adecuada a la magnitud de lo que ésta representa, descartando las indemnizaciones simbólicas".

75 SESSARIEGO, "Protección a la persona humana", cit, 60.

76 "El daño fundado en la dimension del hombre en su concreta realidad", in "Daños a la persona", Revista de Derecho Privado y Comunitário, T. 1, Ed. Rubinzal-Culzoni, Buenos Aires, 1995, 30.

Revista da Faculdade de Direito da UFRGS, v. 19, Març/2001
Recomendaram ainda os congressistas, de lege ferenda, a incorporação, ao Código Civil, de normativa sistemática que hierarquizasse, na órbita privada, os direitos personalíssimos (recomendação XIII, unânime), a ampliação da legitimação das vítimas indiretas do dano ( recomendação XIV, unânime) e a especial proteção da vida humana nascente, resguardando os valores éticos que comprometam a sua dignidade (recomendação XV, unânime) $)^{77}$.

Presente estas recomendações, assinal Moisset Iturraspe que os Tribunais argentinos acompanharam o avançar da doutrina, instalando novas fronteiras aos danos à pessoas, ressaltando a Corte Suprema de Justicia de La Nación, nos últimos anos, "su preocupación intensa por salvaguardar la dignidad, el honor la intimidad de las personas ${ }^{78}$ ",

Embora não formulado expressamente na Constituição argentina, como ocorre na brasileira, o princípio da dignidade da pessoa tem sido deduzido pela jurisprudência dos Tratado Internacionais, assim a Declaração Americana dos Direitos do Homem e do Cidadão, a Convenção Americana dos Direitos Humanos, acolhidos com hierarquia constitucional. Por esta via, os direitos da personalidade, decorrentes do princípio, têm sido objeto da mais recente e crescente atenção doutrinária e jurisprudencial ${ }^{79}$.
Comprova esta afirmativa o texto proposto $^{80}$ em 1998 pela Comissão encarregada da redação de um Projeto de Código Civil ${ }^{81}$, coordenada por Atilio Anibal Alterini: o Código projetado é claramente voltado à proteção da personalidade e, por conseqüência, pleno de cláusulas gerais que permitem caracterizar ampliadas hi póteses de danos à pessoa. Sua novidade e a minudência com a qual trata o tema ensejam uma referência particularizada, ainda que incompleta, aos artigos nos quais o princípio da dignidade da pessoa vem posto, ou pressuposto, como fundamento do dever de indenizar.

A referência deve iniciar pelo art. 105 que fundamentando expressamente este dever na lesão aos direitos da personalidade já tradicionalmente consagrados, enseja, contudo, a possibilidade de acolhimento da novos bens jurídicos. Vale a pena reproduzir a sua letra, pela qual "la persona humana afectada en su intimidad personal o familiar, honra o reputación, imagen o identidad, o que de cualquier modo resulte menoscabada en su dignidad personal, puede reclamar la reparación de los daños sufridos". A expressão "de qualquer modo", caracterizando a cláusula geral que poderá permitir, caso aprovado o Projeto, o desenvolvimento, por via judicial, de novas hi póteses.

A imagem, uma das projeções sociais da personalidade, vem especialmente tutelada no

" Arrolamento das "recomendaciones" segundo MOSSET ITURRASPE, "El danõ fundado en la dimension del hombre", in Revista de Derecho Privado y Comunitario, cit, 31 e 33.

z8 "El danõ fundado en la dimension del hombre", in Revista de Derecho Privado y Comunitario, cit, 35 a 37.

7 Para estes esclarecimentos, agradeço a sempre solidária colaboração da Professora Doutora Noemi Lidia Nicolau, da Universidad de Rosario, Argentina.

so http://www.alterini.org

sl O Projeto de 1998 está em estudo em uma "Comisión bicameral" (criada pela Câmara de Senadores e Câmara de Deputados da Naçâo), estando presentemente recebendo notas de apoio ou crítca por parte da comunidade jurídica. (Para estas informaçôes, agradeço a colaboração da Professora Doutora Noemi Lidia Nicolau, da Universidad de Rosario,).

Revista da Faculdade de Direito da UFRGS. v. 19, Marco/2001 
art. 107 que inadmite, como regra geral, a re produção da imagem ou da voz sem o consentimento da pessoa. Completa-a o art. 109, que confere direito à vítima do dano, além da ação indenizatória o direito a exigir que atentado cesse imediatamente, sem necesidade de provar culpa ou dolo do autor e ainda solicitar as publicacões que entenda satisfatórias para o desagravo da imagem atingida. Cabe ainda especial referência à normativa do art. 112 , que versa matéria merecedora da atenção dos estudiosos da Bioética, qual seja, o consentimento informado do paciente no caso de submetimento a exames ou tratamentos químicos ou cirúrgicos, disposição que é completada por outras regras que tratam de casos excepcionais ou a flebilizam, em certas circunstâncias (arts. 113 e 114).

A nova normativa argentina de tutela à pessoa deve ser entendida à luz do "princípio da prevenção do dano", acolhido pela cláusula geral do art. 1585, pelo qual "toda persona tiene el deber, en cuanto dependa de ella:a) De evitar causar un daño no justificado.b) De adoptar, de buena fe y conforme a las circunstancias, las medidas razonables para evitar que se produzca un daño, o disminuir su magnitud. Si tales medidas evitaron o disminuyeron la magnitud de un daño, del cual un tercero habría sido responsable, tiene derecho a que éste le reembolse el valor de los gastos en que ha incurrido para adoptarlas, confor me a las reglas del enriquecimiento sin causa (e) c) De no agravar el daño, si ya se ha producido", possibilitando-se, para a observação e efetivação máxima do princípio várias medidas preventivas e punitivas que serão posteriormente aludidas.
$O$ art. 1600 , alínea $b$, ocupa-se em estender o alcance do dano extrapatrimonial, "interfiere en el proyecto de vida, perjudicando a la salud física o psíquica o impidiendo el pleno disfrute de la vida", e ainda aos que causam danos à liberdade, à segurança pessoal, à dignidade pessoal " $O$ en cualesquiera otras afecciones legítimas", disposição que é completada, e ainda alargada, pela do art. 1601 que declara reparável o dano extrapatrimonial direto ou indireto, assim como o dano futuro certo, e mesmo a "perda de uma chance" ("la pérdida de probabilidades") na medida en que "su contingencia sea razonable", proibindo o art. 1642 a exclusão ou limitação de responsabilidade por este dano ${ }^{82}$

Já o art. 1689 realiza a opção pela expressão "dano extrapatrimonial", estendendo a legitimação para a ação, nos termos da seguinte cláusula geral: "La persona humana damnificada directa tiene legitimación para accionar por la satisfacción de su daño extrapatrimonial. Si sufre gran discapacidad, o del hecho danôso resulta su muerte, también tienen legitimación a titulo personal, según corresponda conforme las circunstancias, el cónyuge, los descendientes, los asciendientes, y quienes convivían com ella recibiendo trato familiar ostensible. Los tribunales tienen atribuciones para asignar legitimación a otros sujectos, en los casos especiales en los que el hecho tiene un grado de repercusión en el reclamente que excede com el damnificado y las demás circunstancias".

Tanto no Projeto do Código Civil Brasileiro quanto no Argentino e na Constituição do Brasil, a previsão legislativa do dano moral vem aludindo expressamente àquele que del ordinario, habida cuenta de su vinculación

22 Para o aprofundamento do exame destas disposiçōes veja-se os comentários de ATÍLIO ALTERINI in "Informe Sobre la Responsabilidad Civil en El Proyecto Argentino de Codigo Civil de 1998", Revista da Faculdade de Direito da UFRGS, 11, 1999, 22.

Revista da Faculdade de Direito da UFRGS, v. 19, Março/2001 expressa em normas semanticamente vagas, notadamente mediante a técnica das cláusulas gerais. Cabe, pois, examinar, como vêm solucionados os tormentosos problemas da fixação do montante indenizatório e do seu caráter, se reparatório, compensatório ou se dotado de um escopo de exemplaridade que o aproximariam da pena privada.

\section{II- A SATISFAÇÃO DOS DANOS À PESSOA}

A tutela à pessoa, ou mais comumente, aos direitos de personalidade é tema que, por toda a sua riqueza e extensão escapa aos lindes deste exame ${ }^{8}$ que versa exclusivamente da reparação dos danos como conseqüência das normas que impõem o dever de indenizar. Nestes estreitos limites é preciso tratar da liquidação do dano (A), examinando após o caráter da condenação (B).

\section{A. A Liquidação do Dano}

A satisfação do dano não-patrimonia mediante indenização em dinheiro foi tradicionalmente o óbice ao reconhecimento de sua indenizabilidade. No direito anterior ao Código Civil, a doutrina sustentava que o dano moral não obrigava à indenização por não ser suscetível de avaliação pecuniária, considerando Lafayette "uma extravagancia do espírito humano a pretensão de reduzir o damno moral a valor monetarios ${ }^{94}$, opinião que, com maiores ou menores temperamentos, teve largo curso nas décadas seguintes.

Hoje em dia, admitida plenamente a indenizabilidade, a dificuldade está na liquidação, que admite um compósito de formas diversas tendo em vista as concretas fattispecies.

No direito brasileiro esta composição de formas resulta, na responsabilidade civil extracontratual, da peculiar sistematização dada à matéria, vale dizer, da combinação entre a cláusula geral de previsão de indenizabilidade do dano (art. 159) e a limitação, para o efeito da indenização, à abertura da cláusula geral, mediante a remissão a certas regras que estabelecem, em determinadas espécies de dano, formas especiais de reparação $0^{85}$. Por esta razão, apenas na hipótese de não-existência de regra própria da avaliação do dano ou de sua liqui-

83 Cresce em importância a tutela inibitória dos direitos de personalidade. No Brasil, é veículo da tutela inibitónia genérica o art, 461 do Código de Processo Civil, com a redacão dada pela Lein ${ }^{\circ}$ 8.952.94, o qual estabelece que tha acão que tenha por objeto o cumprimento de obrigacão de fazer ou não fazer, o juiz concederá a tutela especifica da obrigação ou, se procedente o pedido, determinará providências que assegurem o resultado prático equivalente ao do adimplemento". Na opinião de SERRIO CRUZ ARENHARD, este dispositivo é capaz de veicular tutelas não apenas condenatórias, mas especialmente mandamentais e executivaslato sensu. Demais disto, "permite a proteção provisória do direito ameaçado de lesão, (...) concebe (...) a realização in natura da pretensão exposta" $e$, " por fim, elenca técnicas de coerção capazes de atuar na vontade do requerido, para impor-lhe a abstenção pretendida", atuando, assim, na proteção a "todas as carências da proteção à vida privada”. ("A Tutela Inibitória da Vida Privada”, Ed. Revista dos Tribunais, 2000, 111).

84 "Direito das Cousas", parágrafo 205, nota 8, apud JOÃO LUIZ ALVES, "Código Civil da Republica dos Estados Unidos do Brazil, $1^{a}$ edição, Ed. F. Briguiet e Cia, Rio de Janeiro, 1917, 1086 e 1087.

25 As espécies não são imóveis. Lembro o que vem ocorrendo nos casos de danos extrapatrimoniais resultantes de infração capitulada na "Lei de Imprensa", que segue o modelo da indenização tarifada, sujeita a "teto": mesmo aí a jurisprudência vem entendendo que "inexiste limite prefixado à indenização resultante de mesmo aí a jurisprudência vem entendendo que "nexiste limite prefixado à indenização resultante de
infração capitulada na Lei de Imprensa quando se trata de conduta dolosa", de modo que "se a quantia for esti pulada no máximo previsto para os casos de ação culposa, deve ser majorada em razão da vontade deliberada de ofender que distingue as duas situaçōes" (RT 616/46). 
dação, lembra Araken de Assis em primoroso estudo, "aplicar-se-á a outra cláusula geral, prevista no art. 1.553, que a remete ao arbitramento'86. Com o que, alcança-se a singular disciplina que associa preceitos do Código Civil ao do Código de Processo Civi ${ }^{87}$.

A compreensão desta disci plina é relevante por uma série de motivos que convém anotar. Primeiramente, a liquidação por arbitramento, que numa leitura estreita do Código Civil denotaria caráter residual - pois às poucas espécies de danos extrapatrimoniais cuja indenizabilidade ali vêm expressamente previstas ligam-se regras próprias de avaliação e liquidação - hoje apresenta-se, quantitativa e qualitativamente como a regra geral.

E assim é por uma dupla ordem de razões, seja em razão da ampliação da fattispecie, espraiada nas cláusulas constitucionais e na legislação especial, de um lado, seja, de outro, porque cuida-se de dar a devida importância às

lesões aos direitos da personalidade, chegando mesmo construção jurisprudencial recente a obstar o alcance restritivo da indenização tarifária do art. 51 da chamada "Lei de Imprensa" (Lei $\mathrm{n}^{\mathrm{o}} 5.250 / 67^{88}$ ), que trata também da indenização do dano não-patrimonial quando perpetrado mediante meios de comunicação de massa ${ }^{a 9}$.

Demais disto, sabe-se que, em matéria de responsabilidade civil vigora o princípio da dupla forma de reparação: ou a restituição in natura ou a indenização stricto sensu. A restauração in natura, dita especifica, significa a reposição das coisas ao estado anterior do dano, a indenização em sentido estrito é a restituição pelo equivalente pecuniário.

No sistema tradicional da responsabilidade civil a pretensão para haver a indenização em dinheiro seria exercida apenas se a restauração em natura não pudesse ser feita, ou se ela não satisfizesse ao credor (Código Civil, art. $1534)^{90}$, o que significa afirmar a centralidade

"Liquidação do Dano", Revista dos Tribunais 759/12

"Liquidação do Dano", Revista dos Tribunais 759/12

\& O art. 51 estabelece tarifa cujo valor máximo para "cada escrito, transmissão ou notícia", de dez salários mínimos nos casos de imputação de fato ofensivo à reputação de alguém, aumentando o art. 52 da mesma les, em dez vezes este valor no caso da responsabilidade civil da empresa que explora o meio de comunicação. Com integral razão afirma ARAKENDE ASSIS. "O advento do art. 50 $\mathrm{m} \mathrm{V}$ e X da Carta em vigor colocou , sob fundament de que a ilícito ocorreu "maliciosamente, de forma insidiosa, por interesses mesquinhos, afastou tais limites, porque não teria sentido pretender que a regra constitucional que protege amplamente os direitos subjetivos privados nascesse limitada pela lei especial anterior ou, pior ainda, que a regra constitucional autorizasse um tratamento discriminatório. E a $4^{\mathrm{a}}$ Turma do STJ, tratando do valor do depósito recursal, previsto no art. 57 parágrafo $6^{0}$ da Lei no $5250 / 67$, admitiu a revogação do art. 51 pela Constituição, e, concebido aquele para a indenização tarifária, estimou inaplicável a exigência". "Liquidação do Dano", Revista dos Tribunais 759, cit, 16. Os acórdãos do STJ referidos são: $3^{z}$ T. STJ, REsp 52.842-RJ, 16.09.1997, rel. Min. Carlos Alberto Menezes Direito, DJ de 27.10.97, p. 54.876, e $4^{\underline{a}}$ T, Resp. 39.886- SP, 22.09.1997, Rel. Min. Sávio de Figueiredo, RJSTJ 10( 103)/245.

* Assim o Acórdão RESP 164421/RJ in DJ de 16/08/1999, p.00073 e RSTJ vol.128, p.372,Relator Min Ruy Rosado de Aguiar, STJ, $4^{\mathrm{g}}$ T. assim ementado: LEI DE IMPRENSA. Legitimidade ativa. Pessoa Ruy Rosado de Aguiar, STJ, 4. T. assim ementado: LEI DE IMPRENSA. Legitimidade attiva. Pessoa
jurídica. Legitimidade passiva. Empresa e jornalistas. Valor da indenização.(...) 3. A indenização por dano jurídica. Legitimidade passiva. Empresa ejornalistas. Valor da indenização.(...) 3. A indenização por dano
extrapatrimonial decorrente de matéria divulgada através da imprensa, em ação de responsabilidade fundada extrapatrimonial deconrente de matéria divulgada através da imprensa, em açâo de respon

so Art. 1534:- 'Se o devedor não puder cumprir a prestação na espécie ajustada, substituir-se-á pelo seu valor, em moeda corrente, no lugar onde se execute a obrigação".

Revista da Faculdade de Direito da UFRGS, v. 19, Março/2001 da reparação em espécie e dizer que a indenização pelo equivalente pecuniário é meramente subsidiária ${ }^{91}$. Embora assim efetivamente tivesse sido o sistema pensado, hoje em dia essa afirmativa não resiste mais ao filtro da realidade. $\mathrm{Na}$ base da centralidade da restituição in natura está a ficção de que encontrando-se a vitima de volta ao statu quo ante, todo o dano foi apagado. A prática também demonstra que atualmente, quantitativa e qualitativamente, é a indenização em dinheiro, e não a restituição pelo equivalente que está a ocupar o "papel central nas modalidades de reparação" 2 .

É que o duplo modelo de reparação ajustava-se perfeitamente bem às lesões patrimoniais, a reparação específica sendo tida como a regra dominante também no direito comparado, como anota Araken de Assis lembrando o Código Civil português e o francês ${ }^{93}$. Por outro lado, mesmo no que diz com a restituição pelo equivalente, o cálculo do montante apresenta, quanto aos danos patrimoniais, dificuldades contornáveis, pois tudo está no terreno da patrimonialidade.

Este modelo reparatório é posto em xeque com a consagração do dano nãopatrimonial e, notadamente, com os atentados aos direitos da personalidade. Certas formas de reparação são tidas apenas "aproximativamen$t e^{g_{4}}$ " como restituição in natura: assim a retratação de alguém ofendido em sua honra. $\mathrm{Ou}$ tras são contrárias à dignidade humana, em especial a regra do art. 1548 do Código Civil brasileiro, que presume dano ao que chama de

9t ARAKENDE ASSIS, "Liquidação do Dano", Revista dos Tribunais 759, cit., 15

2 ARAKEN DE ASSIS, "Liquidação do Dano", Revista dos Tribunais 759, cit, 15.

98 ARAKEN DE ASSIS, "Liquidação do Dano", Revista dos Tribunais 759, cit., 15.

94 A expressão é de PONTES DE MIRANDA, Tratado de Direito Privado, T. 26, cit., parágrafo 3.108, 35, também citado por ARAKEN DE ASSIS, "Liquidação do Dano", Revista dos Tribunais 759, cit., 15.

${ }^{25}$ Código Civil da Republica dos Estados Unidos do Brazil, $1^{a}$ edição, Ed. F. Briguiet e Cia, Rio de Janeiro, 1917,1087 e 1088

Revista da Faculdade de Direito da UFRGS, v. 19, Março/2001 "honra" da mulher e, considerando-a "desonraeparação pelo casamento, tran este ato de afeto que é privilegiada cxisagsiva a fato de a agressor ela não casar, um dote "corresponPropra condreoo escado avalaramente a regra, a meu juízo, inconstitucional -, a mulher que, se virgem e menor, fosse deflorada (inc. I), ou se, "mulher honesta", fosse violentacom promessa de casamento (inc. III) ou se raptada (inc. IV).

Por isto é que na interpretação do

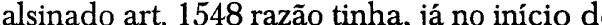
século XX, João Luiz Alves, um dos primeiros propósito do art 1548 observava: "Estabelecendo o Cod., a obrigação de reparar o mal, no caso de estupro, se a mulher for honesta, teve qualquer direito? Não seria justo, nem seria humano. Por mais degradada que seja a muther, resta-lhe sempre o direito de dispor livremente do seu corpo (...). Esta indemnização, certo, não pode ser a devida á mulher honesta,

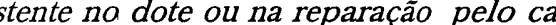
samento, mas terá de obedecer aos principios geraes de direito, nos termos dos arts. $1549 \mathrm{e}$ $1553^{\text {’95 }}$. (iscó 
O que aí se afirmava não era apenas o clamor aos princípios gerais de direito, a isonomia, a equidade ou a razoabilidade, mas, por igual, a forma da liquidação, a ser obtida pela via do arbitramento em todos os casos não especificamente previstos. Esta forma, se residual naquela época, hoje cresce em importância quando "a tendência contemporânea elimina a formulação de regras prévias, deixando ao arbítrio do juiz a avaliação do dano" ${ }^{\circ}$.

A liquidação por arbitramento seria, no meu entender, a solução mais adequada ao tratamento do dano à pessoa ${ }^{97}$ se a jurisprudência brasileira tivesse a compreensão das formas de atenuação dos riscos que a liquidação por arbitramento pode acarretar à segurança jurídica e à isonomia $a^{98}$. Estes serão superados apenas na medida em que os juizes compreenderem a função das cláusulas gerais, o que é dizer, quando lograrem alcançar os modos de operálas, viabilizando a ressistematização das decisões que, atomizadas, díspares em seus fundamentos, provocam quebras no sistema e objetiva in justiça, aotratar desigualmente casos similares.

O ideal, nesta matéria, seria o estabelecimento de "grupos de casos típicos" conforme o interesse extrapatrimonial concretamente lesado e consoante a identidade ou a similitude da ratio decidendi, em torno destes construindo a jurisprudência certos tópicos ou parâmetros que pudessem atuar, pela pesquisa do precedente, como amarras à excessiva flutuação do entendimento jurisprudencial. Facilitada, assim, estaria a pesquisa do precedente e a elaboração, progressiva e aberta de tópicos, nos sentido viehweguiano, obtendo-se, pouco a pouco a ressistematização das fattispecies já previstas e permitindo-se a incorporação de novas hipóteses sem que fosse necessário recorrer à punctual intervenção do legislador ${ }^{99}$.

Assim, sendo progressivamente formados os "tópicos reparatórios" dos danos à pessoa poderiam os juízes furtar-se aos riscos do imobilismo decorrente da fixação legal do montante indenizatório, podendo melhor atender a tarefa de poderação de valores que habitualmente ocorre na tutela da personalidade, até pela freqüente possibilidade de colisão de prin-

๑5 Assim a opinião de ARAKENDE ASSIS, "Liquidação do Dano", cit., e também a de CARLOS ALBERTO BITTAR, que cita. Não é, porém, uma tendência isolada, uma vez que a ela contrapõe-se a da fixação de tarifas, ou "tetos", como no projetado Código Argentino de 1998.

s7 Observa ARAKENDEASSIS que esta forma hamonizase aịda com a dição do art. 606, inciso Il, do CPC, pela qual far-seá a liquidação por arbitramento "quando o exigir a natureza do objeto da liquidação". Contudo, por vezes a jurisprudência prefere as facilidades do estabelecimento do quantum fixo, como expresso no Ac da $1^{g} C$. Civ. do TJR de 19.11.91, Rel. Des. Carlos Alberto Menezes Direito, in RDTJRJ 14/90.

' O que tem ocorrido nos casos de injúria e calúnia, para as quais é prevista, no Código Civil, a adoção da multa criminal como parâmetro. Contudo, a mudança no valor da pena criminal enseja indenização de até 10.800 salários mínimos, ou seja, mais de um milhão e quinhentos mil reais, aproximadamente um milhão de dólares. Explica ARAKEN DE ASSIS: "Ampara a conclusão complexo raciocínio. O art. 49 do Código Penal reza que a pena máxima de multa corresponderá a 360 dias multa, e, segundo seu parágrafo primeiro, o valor do dia multa é de cinco salários mínimos. Logo, 360 X $5+1.800$ salários mínimos. E a multa, conforme consta do art. 60 , parágrafo $1^{\circ}$ do $\mathrm{CP}$ poderá ser triplicada, considerando a condição econômica do réu. Assim, o valor máximo da pena criminal de multa é de 5.400 salários mínimos e, permitindo o art. 1.547 parágrafo único do $\mathrm{CC}$ a aplicação do seu dobro, chega-se à aquele valor assombroso". ("Liquidaçẫo do Dano", cit., 18).

๑ Para o exame das funçôes e modos de operação das cláusulas gerais, ver o meu "A Boa Fé no Direito Privado", cit., 330 a 377

Revista da Faculdade de Direito da UFRGS, v. 19, Març/2001 cípios, como ocorre, paradigmaticamente, nos casos em que a tutela à vida privada choca-se com a liberdade de expressão artística ou de informação jornalística. Por este motivo, a razão novamente está com Ruy Rosado de Aguiar Júnior quando ensina que na concretização das cláusulas gerais "sobressai a responsabilidade do juiz de agir com extremo cuidado ao estabelecer tal norma de dever, que ele usará como parâmetro para resolver o caso", cabendo-lhe ainda "nesse trabalho criador (...) mais do que em outras ocasiões fundamentar as suas decisōes" ${ }^{100}$.

Outras lesões a interesses não patrimoniais, como o dano à vida privada trazem ainda maiores dificuldades, o que tem levado à busca de soluções complementarès à indenização do dano, tal como, na condenação à restituição in natura, a cumulativa imposição de astreintes, para convencer a parte vencida a prestar rapidamente o devido.

Na França, desde 1970 vigora a Lei de 17 de julho que, modificando o art. 9 do Code Civil e determinando que "chacun a droit au respect de sa vie privée”, permite ao juizes, “ sans préjudice de la réparation du dommage subi (de) prescrire toutes mesures, telles que séquestre, saisie et autres, propres à empêcher ou à faire cesser une atteinte à I'intimité de sa vie privée", possibilitando, ainda, que estas medidas, se houver urgência, possam ser "ordonnés en referé".

Entre nós, Sérgio Arenhard, em trabatho recente, verbera a "insuficiência" dos instrumentos tradicionais do processo e nomeadamente da sentença condenatória, para fazer frente,

com eficiência, a certos tipos de lesão extrapatrimonial, notadamente os danos à vida privada, porque, nesses casos, poderá não haver "sentido prático" na sentença pela qual o juiz declarou o demandado responsável pelo ressarcimento de danos e o condenou a indenizá-lo ${ }^{101}$. Nessas situações, pondera o autor, com "pouco mais do que inútil é um provimento capaz, apenas, de exortar (ou convidar) alguém a adimplir determinada prestação" (pois), "ultima ratio, a função da sentença condenatória é, tão-somente, abrir a vencedor o acesso ao processo de execução; é formar um título executivo" ${ }^{102}$.

Na Argentina, o Projeto de 1998 ocupa-se especialmente da tutela preventiva aos danos, conferindo o art. 1586 a atribuição ao tribunal, para "disponer, conforme a las circunstancias, medidas tendientes a evitar la producción de daño futuro", podendo aplicar, conforme o art. 1587, uma multa civil a quem "actúa con grave indiferencia respecto de los derechos ajenos o de los intereses de incidencia colectiva", fixando-se seu montante conforme as circunstâncias do caso.

As astreintes estão previstas no art. 1590 , que confere ao tribunal o poder de impor, ser requerido pela parte, e em seus beneficio, "condenaciones pecuniarias, que pueden ser progresivas, a quien no cumple los deberes jurídicos impuestos en una resolución judicial. Son graduadas teniendo en cuenta la situación patrimonial del destinatario, y pueden ser reajustadas, o dejadas sin efecto, si éste desiste de su resistencia y justifica total o parcialmente su proceder".

100 "O Poder Judiciário e a Concretização das Cláusulas Gerais: Limites e Responsabilidade ”, Revista da Faculdade de Direito da UFRGS, vol. 18, 2000

101 "A Tutela Inibitória da Vida Privada", cit, 161

102 "A Tutela Inibitória da Vida Privada", cit, 161 e 162

Revista da Faculdade de Direito da UFRGS, v. 19, Março/200 
A menção às astreintes leva à consideração do caráter da reparação nos danos à pessoa, introduzindo o tema - entre nós ainda recoberto de "idées recues" - do caráter de exemplaridade da indenização por danos à pessoa.

B. O Caráter Punitivo da Condenação às Perdas e Danos

Quando, no Direito, certo instituto é refuncionalizado para atender novas necessidades, ou a circunstâncias que, mesmo existentes, não eram consideradas dignas de tutela, é preciso que a doutrina não se aferre a dogmas que bem vestiam tão só a função antiga restando, na nova, como roupas mal cortadas, em massa produzidas. É precisamente o que ocorre com a insistência de atribuir-se à responsabilidade civil, como se integrasse a sua própria natureza, um caráter estritamente reparatório, sem nenhum elemento de punição ou de exemplaridade.

Por vezes é melhor ser eterno do que ser moderno, como afirmou o poeta ${ }^{103}$, buscando, na História, os sinais que permitem compreender o presente e visualizar o futuro. "Cercatore di segni" "104, quem compreende o Direito pela História (e haverá outra maneira de compreendêlo, e não apenas aplicá-lo?) deve buscar no tempo que não é só linear cronologia - e superposição e recuperação, é signo e indicação -, os modelos constitutivos daqueles "momentos dialéticos que hay que poner en

contacto y conexión com el patrimonio del que somos portadores" 105

Em 1947, quando Boris Starck publicou na França a sua tese Essai d'une théorie générale de la responsabilité civile considerée en sa double fonction de garantie et de peine privét restou praticamente isolado porque sublinou o caráter sancionatório da reparação a certos ben de vida, sanção perspectivada desde uma finalidade de prevenção e repressão de condutas re prováveis. Apontava então o autor às diversas manifestações do caráter repressivo da responsabilidade, exemplificadas, no ordenamento francês, pela tendência do juiz a aumentar a indenização no caso de o dano ter sido produzido por culpa grave, ou, ao inverso, de reduzir proporcionalmente o valor no caso de culpa concorrente da vítima.

O éclatque acompanhou a tese de Starck deveu-se à sobrevivência de um dogma, qual seja, o que afirmara o caráter puramente restitutivo da reparação civil. Esta não seria jamais contaminada por nenhum elemento repressivo ou punitivo desde que ultrapassado o estágio das sociedades arcaicas. Mais de cinquenta anos passados do trabalho de Starck e a mais de um século da Pandetística alemã caberia ainda razão a von Jhering, segundo o qual a história da pena privada é a história da sua decadência?

Estudos mais recentes têm demonstrado a relatividade, quanto ao menos, do célebre dito de von Jhering. Já nos anos 30 do século trans-

${ }_{103}$ CARLOS DRUMMOND DE ANDRADE, "Eterno", in Antologia Poética, Ed. Sabiá, 5a edição, 237.

lot PAOLO GROSSI, "Pagina Introdutiva" ao volume 27 dos "Quaderni Fiorentini per la Storia del Pensiero Giuridico Moderno", Milão, Giuffrè, 1998.

105 PAOLO GROSSI, Modelos Históricos y Proyectos Actuales en la Formación de un Futuro Derecho Europeu", discurso pronunciado ao receber o Titulo de Doctor Honoris Causa da Pontificia Universidad Católica del Perú, publicaçãoCuadernos del Archivo de la Universidad, 13, Lima, 1999, 33.

${ }^{106}$ Thèse, Paris, 1947. Veja-se, para uma síntese, do mesmo autor, "Domaine et fondement de la responsabilité sans faute", Rev. Trim. Dr. Civ. 1958, 475-515, e Droit Civil - Obligations, LITEC, Paris, 1972, 34 e ss.

Revista da Faculdade de Direito da UFRGS, v. 19, Março/2001 curso Pasquale Voci ${ }^{107}$ afirmava a vitalidade que período clássico. Pena privada, entenda-se bem, não como pena aplicada "pelos privados" ou como resultado de uma "justiça privada", mas como a forma de punição atrelada ao delictum, conceito originalmente próprio ao ius civile (mais tarde estendido ao ius honorarium) e por isto distinto do crimen, ato contrário ao Direito castigado pelo Direito Penal público ${ }^{108}$. Recorro a Max Kaser: "las consecuencias de caráter juridico privado que dimanan de un delito, rebasan la esfera propria de los actualmente llamados actos ilícitos, en cuanto que en el correspondiente proceso civil no sólo se pretende obter un resarcimiento del daño patrimonial sufrido, sino también una pena, esto es, un mal que se inflinge al autor, com el que expie su delicto y procure satisfacción al ofendido" ${ }^{100}$

Não há como não relacionar estas palavras com o teor da fundamentação de acórdão relativamente recente do Tribunal de Alçada do Rio Grande do Sul segundo o qual a natureza da reparação do dano moral consiste em um "misto de satisfação compensatória à vítima e de sanção ao causador do dano, ou seja, deve-se, com a condenação pecuniária, propiciar à vítima uma satisfação, um prazer, que o direito pretoriano conferia à pena privada no sirva de lenitivo à amargura que lhe foi impos ta, ao mesmo tempo em que se pune civilmen te o lesador (SIC), buscando até mesmo efeito repressivo e pedagógico ${ }^{110}$.

Se no Brasil este caráter vem exposto, mas não comentado ou, ao menos, não explicitamente relacionado ao modelo romano, na Alemanha Bernd-Rudinger Kern, catedrático de Direito Privado, em artigo recentemente traduzido para o português assenta, no título, a "função de satisfação na indenização do dano pessoal", para logo no sub-título questionar provocativamente: "um elemento penal na satisfação do dano"?

A provocação já vem de certo modo respondida no primeiro parágrafo do texto: ao referir o leading casena matéria - a decisão do Grande Senado do ano de 1955, seguida uniformemente pela doutrina e jurisprudência sublinha o autor os seus fundamentos, indicativos de que a pretensão deduzida do art. 847 do BGB (que assegura indenização para certos tipos de danos extrapatrimoniais) não configura uma pretensão comum de indenização por perdas e danos, antes constituindo "uma pretensão de natureza peculiar, com dupla função: propiciar ao lesado uma compensação adequada à injustiça que sofre e, ao mesmo tempo, levar
107 Caráter que vem afirmado desde o estudo já vetusto de PASQUALE VOCI, Risarcimento e Pena Privata

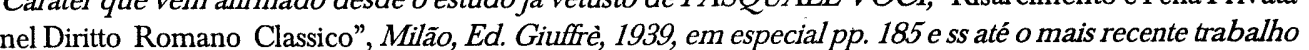
do romanista francês GUILLAUME CARDASCIA, "Réparation et peine dans les droits cunéiformes et le do romanista francês GUILLAUME CARDASCIA, "Réparation et peine dans les droits cunéiformes et le
droit romain", in "La Responsabilité à travers les Ages", MARQUERITE BOULET-SAUTEL et alii, Economica, Paris, 1989, 1-43.

108 FRITZ SCHULZ, Derecho Romano Clásico, Bosch, Casa Editorial, Barcelona 1960, 547 ss. Também MAX KASER, Derecho Romano Privado, Reus, Madri, 1968, 224 e ss.

${ }^{109} K A S E R$, Derecho Romano..., cit., 224 .

Ho xAp. Civ. no 196032965 - $9^{\text {a }}$ Câm. Civ. - Porto Alegre, TARS, Rel. Juiz Antônio Guilherme Tanger Jardim, Revista Julgados do TARGS n ${ }^{\circ}$ 98/407 e 408.

III "A função de satisfação na indenização do dano pessoal -um elemento penal na satisfação do dano?”, in Revista da Faculdade de Direito da UFRGS, vol. 17, Porto Alegre, 1999, 2546, tradução de Lélio Candiota de Campos, publicado originalmente in Archiv für die civilistische Praxis, vol. 191, ano 1991, 247-272. 
em conta que o autor do dano deve ao ofendido uma satisfação pelo que lhe fez"112.

Kern menciona essas duas finalidades, reconhecidas no direito alemão ${ }^{113}$, interpondo, contudo, a tradicional objeção: a de que a função de satisfação "se movimenta perigosamente perto da pena privada”. À função satisfatória agregar-se-iam elementos propriamente punitivos?

A esta objeção responde o civilista alemão com o entendimento que tem sido seguido pelo BGH (Bundesgerichtshof, o Supremo Tribunal Federal) que em 1975 assentou que "um aprimorado conceito de expiação, não necessariamente criminal no sentido do regramento legal (...) impóe que um pesado prejuízo causado ao ser humano não deve permanecer sem uma reparação, no mínimo simbólica"114, reparação que exige "expiação de modo simbólico", o que significa, segundo

Kern, que "o pagamento deve atingir os ofensores como um sacrifício palpável ${ }^{115}$ atuando a satisfação pecuniária em primeira linha contra o ofensor, mas secundariamente de modo preventivo, também sobre o público ${ }^{116}$.

É, em linha de princípio, o entendimento adotado em parte da jurisprudência brasilei$\mathrm{ra}^{117}$ e acolhido na doutrina ${ }^{118}$, que entretanto não relacionam este caráter de expiação e satisfação diretamente com a pena privada romana, mas com o instituto dos punitive damages, ou exemplary damages do direito norte-americano, cabíveis notadamente nos casos de danos extrapatrimoniais coletivos ${ }^{119}$

De toda a forma, ao fundar o valor da verba na relação entre a necessidade de satisfazer, de um lado, a vítima, e, de outro, impor expiação, sacrifício palpável ao lesante, ultrapassa-se outro dogma, conexo ao do caráte puramente restitutivo da responsabilidade civil

II2 "A função de satisfação na indenização do dano pessoal -um elemento penal na satisfação do dano?", in Revista da Faculdade de Direito da UFRGS, vol. 17, 25, com a indicaçâo da fonte original na nota 4.

113 "A função de satisfação na indenização do dano pessoal -um elemento penal na satisfação do dano?", in Revista da Faculdade de Direito da UFRGS, 26.

${ }^{1 / 4}$ Apud Bernard-Rüdiger Kern, "A função de satisfação na indenização do dano pessoal -um elemento penal na satisfação do dano?", in Revista da Faculdade de Direito da UFRGS, cit., 30 .

115 "A função de satisfação na indenização do dano pessoal -um elemento penal na satisfação do dano?", in Revista da Faculdade de Direito da UFRGS, cit, 30.

116 "A função de satisfação na indenização do dano pessoal -um elemento penal na satisfação do dano?", in Revista da Faculdade de Direito da UFRGS , cit., 30.

${ }_{I I 7} \mathrm{Vg}$, o acórdão proferido pelo TJRGS na Ap. Civ. no 596.210.840, $5^{\mathrm{a}}$ Câm. Civ., j. 21.11.96, rel. Des. Araken de Assis, in RT 738/402, assim ementado: 'O banco credor é responsável pelo dano moral provocado contra homônimo, executado em lugar do verdadeiro obrigado, pois a execução se realiza no seu interesse, devendo o valor da indenização atender ao exemplary damages".

II CAIO MARIO DA SLVA PEREIRA, "Responsabilidade Civil", n. 49, 67, Rio de Janeiro, 1989, CARLOS ALBERTO BITTAR, "Reparação civil por danos morais", São Paulo, 1993, 202.

${ }^{11}$ Também a doutrina argentina sinaliza neste sentido, Veja-se a relação apresentada por Ricardo Luis LORENZETTI ao Colloquio Internazionale "L 'unificazione del Diritto in América Latina: principi e regole comuni in materia di responsabiliti extracontrattuale.

Revista da Faculdade de Direito da UFRGS, v. 19, Março/2001 qual seja, a não-incidência, na fixação do quantum, do dever de proporcionalidade, também dito princípio da proporcionalidade.

O Projeto do Código Civil prevê no parágrafo único do art. 946 regra que atenua o princípio da identidade entre o dano e o quantum da reparação, estatuindo: "Se houver excessiva desproporção entre a gravidade da culpa e o dano, poderá $o$ juiz reduzir, equitativamente, a indenizaçâo", determinando o art. 947 que, na hi pótese de concorrência de culpa entre a vítima e o autor do dano, "a sua indenização será fxada tendose em conta a gravidade de sua culpa em confronto com a do autor do dano".

Não muito diverso é o panorama do direito argentino, ao menos do direito projetado ${ }^{120}$. $\mathrm{O}$ art. 1621 do Projeto Alterini, ao traçar regras gerais de reparação, distingue entre os quatro modos diversos, segundo o caso, quais sejam, a reposição ao estado anterior ao dano; a restituição do que o responsável está obrigado a devolver, do que obteve indevidamente; o ressarcimento do valor do dano patrimonial e a satisfação do valor do dano extrapatrimonial (alínea d). O termo " satisfação" volta a ser empregado no art. 1640, que trata especialmente do dano extrapatrimonial e que estatui: " $E l$ acreedor tiene derecho a requerir que el daño extrapatrimonial sea satisfecho, total o parcialmente, mediante el pago de dinero, o de otro modo distinto. El tribunal, según las circunstancias, dispone lo que corresponde; en los casos de lesiones a la dignidad personal puede ordenar la publicación de la sentencia".

À vista do caráter satisfatório, e não restitutivo, os tribunais têm, em certas circunstâncias, atribuições para determinar a atenuação da responsabilidade, por razões de equidade, conforme preceitua o art. 1641, segundo o qual

\footnotetext{
120 Veja-se a exposição de ROBERTO LOPES CABAÑA, no mesmo Colloquio.

${ }^{22 I}$ "Unidad Jurídica Europea y Derecho Romano", in "Derecho y Argumentación Histórica", cit, 120.
}

o Tribunal tem essa competência em certas hipóteses, desde que fundado em razões de eqüidade, considerando, entre outros fatores, a situação patrimonial do devedor, " $y$, en su caso, a la circunstancia de que el damnificado haya percibido la indemnización proveniente de un seguro personal", ou se "el hecho dañoso fue causa de ventajas para el acreedor", cabendo também a atenuação na responsabilidade por fato involuntários e nos demais casos previstos em lei.

Parece assim evidente que a tendência, nos diversos ordenamentos, é agregar às funções compensatória - ou simbolicamente compensatória - e punitiva, a função pedagógica, ou de exemplaridade, de crescente importância nos danos provocados massivamente, seja no âmbito das relações de consumo, seja no dano ambiental, ou nos produzidos pelos instrumentos de mass media. Este caráter de exemplaridade guarda, incontroversamente, nítido elemento penal, ao menos se tivermos, da pena, a lata e até intuitiva definição que lhe foi atribuída por Grotius: "Malum passionis quod inflingitur propter malum actiones", ou seja, pena é o padecimento de um mal pelo cometimento de outro.

\section{$* * *$}

Os traços que procurei aqui reunir desenham o tema "danos à pessoa" como uma daqueles paradoxos que a História frequentemente propõe: traz a perplexidade dos novos problemas, axiológicos ou tecnológicos, fazendo repensar questões que pareciam sepultadas pela História, como a introdução de elemento penais na responsabilidade civil e assim suscitando o que o romanista alemão Rolf Knutel, Professor na Universidade de Bonn chamou de "retorno das figuras jurídicas"121. Um "retorno", é bem verdade, entendido na acepção histórica, que se dá sempre no tempo presente, jamais é simples "transposição" porque "Direito" é uma palavra que só se realiza no seu tempo. 